\title{
El cine y las relaciones culturales entre México y Estados Unidos durante la década de $\mathbf{1 9 3 0}$
}

Seth Fein

CASE WESTERN RESERVE UNIVERSITY

\begin{abstract}
Se examina el papel que el cine desempeñó en las relaciones políticas, ideológicas y culturales entre México y Estados Unidos en la época en que se consolidaron las bases para el desarrollo de vínculos de colaboración estable entre ambos países en los años cincuenta.
\end{abstract}

L

os años de 1930 marcaron una época decisiva en la formación de muchas de las estructuras, procesos y prácticas que implica la relación entre los medios de comunicación estadunidenses y la política exterior de Estados Unidos-en especial las interacciones entre el gobierno y las industrias culturales- que iba a ser institucionalizada durante la segunda guerra mundial en el contexto de América Latina, y modernizada y globalizada durante la guerra fría. Estas transformaciones en la política exterior estadunidense y el involucramiento internacional de Hollywood en los primeros años de su producción filmica sonora, coincidieron con un periodo de formación y expansión decisivo del Estado mexicano y de intenso desarrollo en la industria filmica mexicana. A lo largo de los años de 1930, a pesar de los giros en las políticas estadunidense y mexicana hacia los medios de comunicación extranjeros, continuaron desarrollándose vínculos filmicos transnacionales entre México y Estados Unidos, con importantes implicaciones ideológicas respecto a la representación popular de México y de las relaciones Estados Unidos-México. En este ensayo se ana- 
liza el papel del cine en las relaciones políticas, ideológicas y culturales entre México y Estados Unidos durante ese periodo que, a pesar de episodios de conflicto, produjo la estructura para establecer relaciones interestatales más estables y colaboradoras que se fortalecieron en las décadas de 1940 y 1950. ${ }^{1}$

México, los mexicanos y los mexiconorteamericanos han proporcionado un principal "otro" cultural en las películas estadunidenses desde la época de la producción fílmica muda. La historia política y social que vincula a Estados Unidos y México significó que éste se convirtiera en una fuente clave de contraimágenes del progreso, la sobriedad y la virtud estadunidenses. Los estereotipos masculinos negativos de greasers y bandidos y los estereotipos femeninos que alternaban entre seductoras de piel oscura (no menos degradadas que sus contrapartes masculinos) y mexicanas de piel clara más virtuosas, que invariablemente preferían los intereses anglo-

\footnotetext{
1 Este artículo se concentra en el cine y en las relaciones culturales. Considera, sobre todo, la producción de representaciones estadunidenses sobre México y no las imágenes mexicanas sobre Estados Unidos, un tema importante que obviamente forma parte integral de un entendimiento en las relaciones culturales Estados Unidos-México. La ponencia original -"El cine, el Estado mexicano y la política exterior de Estados Unidos"- (de la que es una adaptación) relacionaba los temas culturales, ideológicos y políticos analizados más adelante con el desarrollo de la industria filmica mexicana y las interacciones económicas de Hollywood con el Estado mexicano en la década de 1930. El autor agradece a Aurelio De los Reyes sus comentarios a la versión anterior, que fueron importantes para escribir este ensayo.
}

románticos a los mexicanos, eran la norma en las películas de Hollywood anteriores a la segunda guerra mundial. $^{2}$

Antiguos conflictos culturales sobre representación, entre Hollywood y México, estimularon al Estado mexicano a apoyar, en general, el desarrollo de una industria fílmica sonora doméstica y, en particular, la producción de películas de orientación nacionalista, a principos de los treinta. Eso también provocó que políticas exteriores mexicanas impidieran la proyección de películas que el Estado considerara denigrantes. Diplomáticos estadunidenses en México reconocieron la importancia de un acuerdo filmico recíproco en 1933, entre los gobiernos mexicano y español como un arma de nacionalismo cultural dirigida a Holly. wood. ${ }^{3}$ El acuerdo establecía una cen-

2 Para el retrato de México y los mexicanos en las películas estadunidenses de fines de los años veinte $y$ de los años treinta, $y$ algunos conflictos entre Hollywood y el gobierno mexicano relacionados con esas representaciones, véase Cortés, "To view", 1989, pp. 91-105; Delpar, "Goodbye", 1984, pp. 34-41; Delpar, Enormous, 1992, pp. 169-175; Woll, Latin, 1980, pp. 131. 152 y pp. 202-236; García Riera, México, 1987. pp. 146-257, y México visto por el cine extran. jero: filmografía, 1906-1940, 1987.

3 "Exchange of Notes, Mexico and Spain, Regarding Motion Pictures Derogatory to Either Countryn, William P. Cochran, Jr., vicecónsul de Estados Unidos, Consulado General Norteamericano, ciudad de México al Departamento de Estado (State Department, en adelante citado como SD), 7 diciembre 1933, Archivos Na. cionales de Estados Unidos (U.S. National Archives), Washington, D.C., Grupo de Registro 59 (National Archives, en adelante citado como NA GR 59) 812.4061 Motion Pictures (en adelante citado como MP)/131. 


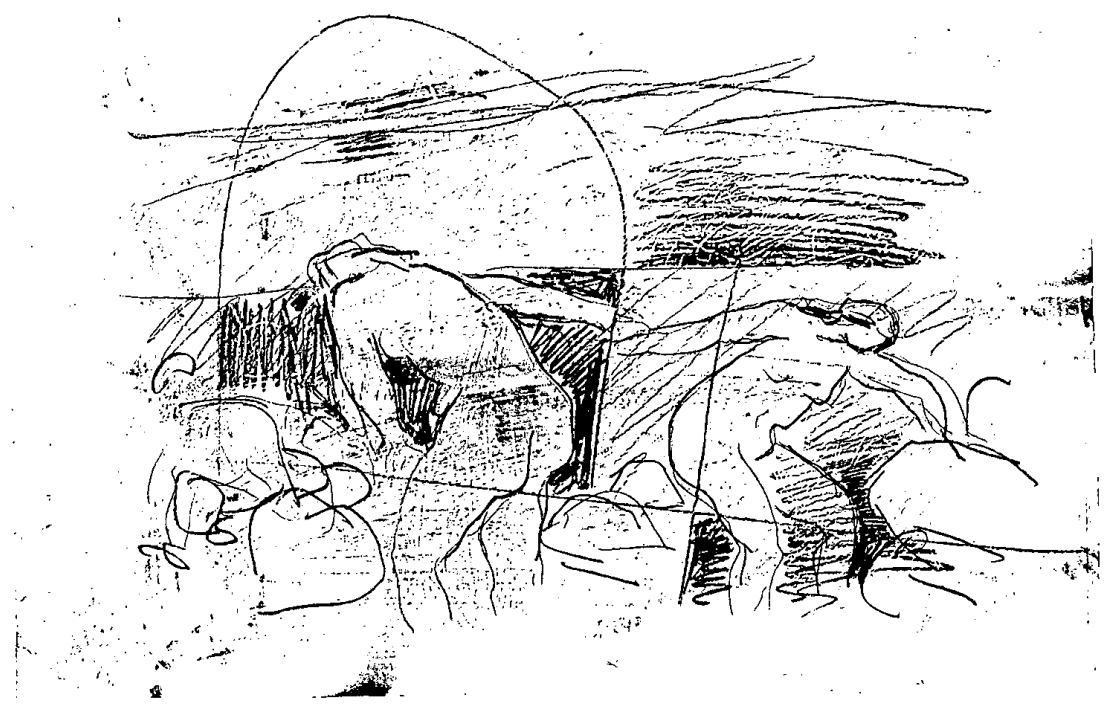

sura de las películas que fueran difamatorias para cualquiera de ambos países e imponía sanciones contra los distribuidores extranjeros que violaran las nuevas disposiciones. España y México también acordaron extender sus sanciones bilaterales contra "Ias películas que se consideren denigrantes para cualquier otro país hispanoamericano". ${ }^{4}$ México inició el proyecto como un primer paso hacia un sistema de protección cultural que

${ }^{4}$ Embajador Genaro Estrada, San Sebastián, España, a Secretaría de Relaciones Exteriores (en adelante citada como SRE) 8 agosto 1933; "Convenio entre México y España para impedir la circulación de películas denigrantes", 5 septiembre 1933, Madrid, III-139-6, Secretaria de Relaciones Exteriores, Archivo Histórico, Ciudad de México (en adelante citado como SREAH). abarcara toda América Latina. ${ }^{5}$ Su meta era proteger su imagen internacional -en gran medida controlada por Hollywood-a través de una cooperación interestatal que restringiera las películas desfavorables y en el proceso influye-

${ }^{5}$ A mediados de los años treinta, como informó un diplomático mexicano, México estable. ció un sistema diplomático regional para confrontar la representación de Hollywood: "México puso en juego inmediatamente su diplomacia y su influencia política en el exterior, gestionó y recibió el apoyo de los países hermanos, se valió de hábiles recursos económico-coactivos, y Costa Rica cooperó amplia y liberalmente con nuestro país, y poco a poco cesó la campaña denigrante que contra nuestros pueblos se había emprendido", véase Salvador Martínez de Alva, "La película mexicana en Costa Rica", Legación de México, San José, Costa Rica, 16 enero 1937, p. 5, III-165-23, SREAH. 
ra en las representaciones elaboradas por Hollywood sobre México y, en general, sobre América Latina. Junto con otra legislación relacionada con la hegemonía cultural de la industria filmica estadunidense en México, las políticas nacionalistas mexicanas para películas extranjeras $-y$ en especial sus ramificaciones internacionales para otros mercados de habla españolaprovocaron una nueva sensibilidad en Hollywood acerca de sus representaciones sobre México en el inicio de la década de 1930.

A medida que Hollywood se expandió internacionalmente en la época del cine sonoro, haciéndose más dependiente de los ingresos externos, la industria filmica estadunidense y el Departamento de Estado se hicieron más conscientes de las ramificaciones diplomáticas de su representación sobre otras nacionalidades. ${ }^{6}$ Con el advenimiento del sector privado y de las políticas gubernamentales de Buena Vecindad -adecuadas a la economía política del hemisferio occidental durante la depresión- la cultura de masas se convirtió en un rasgo central de

${ }^{6}$ El 28 de diciembre de 1931, el Departamento de Estado emitió una instrucción a todos los puestos diplomáticos estadunidenses en América Latina solicitando información, de parte de la MPPDA, sobre la proyección de cualquier película estadunidense considerada ofensiva a los Estados y sociedades latinoamericanos, véase NA RG 59, $810.4061 \mathrm{mP} / 14$ Washington, D.C. Para una interpretación, basada en documentos de la MPPDA, del papel de factores internacionales diplomáticos y económicos en el desarrollo de representaciones hollywoodenses de las nacionalidades, incluido México, véase Vasey, "Foreign", 1992, pp. 617-642. las relaciones exteriores de Estados Unidos. Dentro de este movimiento, a fines de 1933, Hollywood y el Departamento de Estado solicitaron respues. tas de los diplomáticos estadunidenses en América Latina sobre las reacciones negativas oficiales y populares producidas por las películas estadunidenses. La iniciativa provino de la Motion Picture Producers and Distributors of America (MPPDA), organización que representaba los intereses políticos y económicos de Hollywood tanto nacionales como internacionales. La MPPDA quería impedir políticas culturales nacionalistas. Con este fin, cooperó con el gobierno mexicano al aceptar que un inspector mexicano honorario revisara la producción de Hollywood para y sobre México. ${ }^{7}$ El Departamento de Estado apoyó esos esfuerzos porque servían a la política estadunidense en el hemisferio que, aun antes de la administración de Franklin Roosevelt, evolucionaba hacia una mayor sensibilidad cultural y hacia la construcción de un sistema hemisférico neoimperialista menos conflictivo. ${ }^{8}$

A mediados de los años treinta, cuando se afirmó la política de Buena Vecindad, el gobierno tomó la iniciativa de acuerdo con los informes diplomá-

${ }^{7}$ Embajada Mexicana, Washington, D.C., a la SRE, 12 abril 1933; Eduardo Vasconcelos, Secretaria de Gobernación a SRE, 6 noviembre 1933; Manuel Vera Rivera, SRE a Embajada Mexicana, Washington, D.C., 16 noviembre 1933; Embajada Mexicana, Washington, D.C., a SRE, 23 noviembre 1933 , III-136-7, SREAH.

${ }^{8}$ La obra clásica sobre el establecimiento de este estilo más cooperativo de diplomacia en México es, todavía, Freeman, United, 1972; véase también Wood, Making, 1961. 
ticos acerca de que el flujo de películas y noticieros estadunidenses sin censura perjudicaba a los intereses políticos de Estados Unidos

a través de la idea establecida en las mentes inmaduras de muchos latinoamericanos, y en muchos de sus mayores supuestamente con mayor criterio, de que Estados Unidos es un país de vividores disolutos, despreocupados de la moral sexual, y dominado por gángsters, chantajistas y rufianes, y asimismo un país en el que prevalecen las costumbres bárbaras.

Se recomendaba la supervisión gubernamental de las exportaciones de Hollywood a América Latina si los productores estadunidenses no podían ser obligados a autorregularse suficientemente. ${ }^{9} \mathrm{Al}$ parecer el Departamento de Estado consideró que los latinoamericanos eran demasiado deficientes intelectual y culturalmente para confiarles películas sin censura.

El Departamento de Estado pidió que la MPPDA ejerciera su influencia no sólo para limitar la distribución hemisférica de películas degradantes para los latinoamericanos, sino también para censurar las que representaban aspectos de la vida estadunidense -como las relaciones raciales y laborales- perjudiciales a sus objetivos políticos en América Latina. Rechazando la censura directa del Departamento de Estado, el secretario de Estado Cordell Hull escribió al presidente de

9 Véase Leo R. Sack, embajador de Estados Unidos en Costa Rica a SD, 22 diciembre 1933. "Películas exportadas a Latinoamérica", NA RG 59, $810.4061 \mathrm{MP} / 15$. la MPPDA, Will Hays, que Hollywood debería

cuidar en especial que las peliculas y los noticieros enviados al extranjero para su exhibición fueran seleccionados considerando no sólo su interés para los públicos extranjeros, sino también la imagen de aquellas fases de la vida estadunidense que reflejaran el máximo crédito posible sobre este país. ${ }^{10}$

De acuerdo con aceptar la responsabilidad de supervisar la diplomacia de películas estadunidenses, la MPPDA amplió el papel casi público que había asumido en los años veinte de supervisar la censura doméstica de las películas de Hollywood. Esto también representó un paso crucial en el desarrollo de la relación informal del Departamento de Estado con Hollywood, que se profundizó a lo largo de los años treinta, abarcando a otras instituciones no gubernamentales involucradas en programas de películas en América Latina, y especialmente en México-el país más importante para la política exterior estadunidense en el hemisferio-, que poseía el sistema de exhibición de películas sonoras más desarrollado de América Latina. ${ }^{11}$ Este proceso

10 Division of Latin-American Affairs, memorándum, SD, 28 mayo 1934, 810.4061 MP/21; Cordell Hull a Will Hays, 15 octubre 1934, Hays a Hull, 17 octubre 1934, Hull a Hays, 18 octubre 1934, NA RG 59,810.4061 MP/24; Instrucción del Departamento de Estado a los jefes de todas las misiones diplomáticas en Latinoamerica, 31 octubre 1934, "American Motion Pictures", NA RG 59, 810.4061 MP/23.

1 Aunque México ocupaba el tercer lugar en el número de cines en América Latina, era el 
es evidente en el caso de 'Viva Villa!, estrenada por la MGM en 1934.

iViva Villa! representa una de las muchas controversias que involucran al gobierno mexicano y a la industria filmica estadunidense en torno a la representación hecha por Hollywood sobre la cultura y la historia mexicanas en los años treinta. Como su tema se refiere a una de las figuras principales de la revolución mexicana, es particularmente importante para entender por qué la interpretación hollywoodense de la historia mexicana motivó al Estado mexicano a intervenir en su sector fílmico doméstico y a tratar de influir en Hollywood a través de la colaboración; también proporciona contexto para las interacciones en desarrollo entre Hollywood y el gobierno estadunidense durante la etapa temprana de la política de la Buena Vecindad.

Varios estudios cinematográficos estadunidenses pensaron en hacer una película sobre Pancho Villa a principios de los años treinta. El interés de Hollywood en Villa representaba la importancia que tenía el jefe revolucionario mexicano del norte para la imaginación estadunidense. La figura de Villa, el bandido cuyas acciones implicaron invasiones fronterizas de ciudades estadunidenses y conflictos militares con su ejército, representaba la historia política que abarcaba a ambos países; era la imagen del forajido mexicano en la imaginación estadunidense (en buena medida desarrollada por Hollywood), así como la figura princi-

primero en cines con cableado para sonido. Véase Motion, 1931, pp. 3, 4. pal -accesible a los estadunidensesinvolucrada en un acontecimiento clave de la historia mundial, la revolución mexicana, en el país vecino. ${ }^{12}$

Desde la concepción de una película de Villa por Paramount en 1931, su desarrollo implicó negociaciones entre los estudios, la MPPDA y el gobierno mexicano. La Production Code Administration (PCA) de la MPPDA -agencia de Hollywood que censuró las películas de los estudios a partir de los años veinte hasta los sesenta-, supervisó de cerca el desarrollo del proyecto. En 1931, la MPPDA prometió al gobierno mexicano "que en todas las cuestiones que impliquen a México, el señor Hays va a contactar personalmente al señor [Genaro] Estrada", secretario de Relaciones Exteriores de México. ${ }^{13} \mathrm{La}$ PCA alentó a los principales ejecutivos de Paramount -incluidos el director ejecutivo de Producción, Ben Schulberg; el jefe del departamento de escritores y guiones, David Selznick; el que se intentaba que fuera su director, Josef von Sternberg-, a que viajaran a la ciudad de México para consultar con funcionarios del gobierno mexi-

12 Como es de suponer, el propio Villa participó en la filmación de sus acciones en la revo. lución mexicana mediante la colaboración -incluidas escenificación y reescenificación de batallas-, del noticiero de la Mutual Film Corporation. El estudio más completo sobre la representación de Villa por 'productores del cine estadunidense se debe a De los Reyes, Villa, 1985; véase también De Orellana, Mirada, 1991, y Cortés, To view, 1989, pp. 95-98.

13 Memorándum procedente de Jason Joy, 8 febrero 1931, PCA, Viva Villa, exp. Margaret Herrick Library, Academy of Motion Picture Arts and Sciences, Beverly Hills, California [en adelante citado como $\mathrm{MHL}$ ]. 
cano antes de emprender la producción. ${ }^{14}$ Paramount (y después RKO y MGM) cooperaron enviando material del relato y versiones del guión para su revisión oficial por la PCA y por el cónsul mexicano en Los Ángeles, que regularmente consultaba con la Secretaria de Relaciones Exteriores en la ciudad de México. ${ }^{15}$ Comentando sobre representaciones de México hechas por Hollywood en el pasado, el director exterior de la MPPDA Frederick Herron (que estaba a cargo de las relaciones comerciales de Hollywood a nivel mundial) advirtió lo siguiente:

[Los estudios] están cometiendo impunemente un crimen con su material mexicano allá, pero tarde o temprano van a tener problemas, $\tan$ cierto como que hay mañana $\{. .$.$] La más ligera chis-$ pa toca a esa gente de mala manera y nosotros somos totalmente impoten tes cuando la llama se prende; lo único que podemos hacer es mantenernos al margen del incendio difundido y permitir que él solo se apague. Pero mientras tanto, toda la industria sufre, así como la compañía en particular. ${ }^{16}$

RKO emprendió la producción de una película sobre Villa después de que Selznick se trasladó allí a mediados

14 Jason Joy, memorándum, 18 febrero 1931 , PCA, exp. Viva Villa, MHL; Joy, memorándum, 21 febrero 1931, PCA, exp. Viva Villa, MHL; Joy, memorándum, 4 marzo 1931, PCA, exp. Viva Villa, MHL; Joy, memorándum, 11 marzo 1931, PCA, exp. Viva Villa, MHL.

is Richard Diggs, Jr., Paramount, a MPPDA, 26 febrero 1931, PCA, exp. Viva Villa, MHL; John V. Wilson, memorándum, 14 diciembre $1931, \mathrm{PCA}$, exp. Viva Villa, MHL.

${ }^{16}$ Frederick L. Herron a Jason Joy, 13 marzo 1931, PCA, exp. Viva Villa, MHL. de 1931. El nuevo proyecto se iba a basar en el libro Here comes Pancho Villa escrito por el mexicano Ramón Puente. Frank Fouce, un empresario de cine de Los Ángeles (con experiencia de negocios en la industria del espectáculo mexicana y mexiconorteamericana) llevó los derechos del libro de Puente a RKo y se ofreció para hacer de intermediario con el gobierno mexicano. ${ }^{17}$ Fouce, a instancias de la MPPDA, redactó un memorándum con el esbozo de cómo representar la vida de Villa para obtener la aprobación oficial mexicana. En cuanto a los aspectos políticos e históricos, Fouce recomendó que la película abordara

17 Edward Montagne (Scenario Editor, RKO) a Jason Joy, 9 agosto 1932, PCA, exp. Viva Villa, MHL; John V. Wilson, memorándum, 19 agosto 1932, PCA, exp. Viva Villa, MHL; Wilson memorándum, 23 agosto 1932, PCA, Exp. Viva Villa, MHL; Wilson, memorándum, 13 septiembre 1932, PCA, exp. Viva Villa, MHL. Fouce fue un intermediario clave entre los intereses estadunidenses y la industria cinematográfica mexicana durante toda la época dorada del cine mexicano. De herencia española, había estado involucrado en la producción de Hollywood de películas en español y poseía cines con películas en español en Los Angeles en los años treinta. A través de estas actividades cultivaba contactos con Hollywood y con empresarios de medios de comunicación mexicanos como Emilio Azcárraga. Más tarde prestó servicios en la Oficina del Coordinador de Asuntos Interamericanos del gobierno estadunidense en tiempo de guerra como asesor sobre la industria cinematogrífica mexicana, y después de la guerra construyó una red de estaciones de televisión en lengua española por todo el sudoeste de Estados Unidos. Dickson proporciona excelentes antecedentes de la carrera no gubernamental de Fouce en "El teatro Cálifornia, una tradición", y "El teatro California y el legado", 1 y 8 marzo 1992, sección $\mathrm{E}$, pp. 1, 4 y pp. 3-4, respectivamente. 
sólo la carrera de Villa previa a su invasión de Columbus, Nuevo México en 1916, y que debería "evitar toda referencia a órdenes y actos procedentes de un gobierno mexicano constituido". Socialmente, la película debería "evitar todas las escenas que desprestigien al pueblo mexicano". Los mexicanos deberían estar representados de una manera digna, respetuosos de las mujeres, no francamente antiestadunidenses y "con una cuidadosa selección de tipos" que no identificara a los villistas como "forajidos". En cuanto al propio lider revolucionario: "Representar los actos buenos o malos de Villa como características individuales [...] más que como características típicas de su raza." Fouce también indicaba que se acentuaran "los aspectos bellos de la ciudad de México para compensar el aspecto de localidades humildes o rurales". ${ }^{18}$ En busca de una política filmica internacional que expandiera los mercados exteriores a todos los estudios importantes, los funcionarios de la MPPDA esperaban que una representación sensible de la historia de Villa -siguiendo las líneas indicadas por Fouce- "resarciría mucho del daño que muchas otras películas han provocado" en las relaciones de Hollywood con el gobierno mexicano. ${ }^{19}$

Selznick de nuevo se llevó consigo la idea de una película sobre Villa cuan-

${ }^{18} \mathrm{John} \mathrm{V}$. Wilson, memorándum, 19 agosto 1932 , sobre la reunión con Fouce, incluido "Recommendations on the Pancho Villa film", de Fouce, PCA, exp. Viva Villa, MHL.

19 Jason a Frederick Harron, 18 marzo 1931, PCA, exp. Viva Villa, MHL. do se trasladó a la MGM. Los estudios adquirieron los derechos de la novela histórica de Edgcomb Pinchon, , Viva Villa!, a partir de la cual finalmente se produjo una película. Cuando Ben Hecht y Jack Conaway (bajo la guía de Selznick) produjeron un guión a partir del libro, la PCA advirtió al jefe de pro. ducción de la MGM, Irving Thalberg, que "debía tenerse el mayor cuidado en omitir cualquier incidente o personaje cuya representación pudiera ser considerada antagónica por el régimen político que ahora controla México". Asegurar la aprobación gubernamental mexicana

del guión y de la producción terminada sería esencial para aventurarse en una historia de este tipo, abordando el ascenso del partido revolucionario de México y de los hombres involucrados en el proceso, la mayoría de los cuales son en la actualidad poderosos en la política y la administración del país.

Se advertía fuertemente que elguión se debía hacer llegar a "los jefes del gobierno mexicano en la ciudad de México" si se quería que el proyecto siguiera su curso. ${ }^{20}$ A fines de 1933 , Selznick aseguró a la PCA que el guión "tenía el visto bueno oficial del gobierno mexicano". 21

La filmación de ;Viva Villa! empe. zó en México. Después de varias complicaciones (incluida la detención del actor de apoyo Lee Tracy, quien ebrio

20 James Wingate a Irving Thalberg, 6 marzo 1933, PCA, exp. Viva Villa, MHL.

${ }_{21}$ Wingate a Edward J. Mannix, MGM, 8 noviembre 1933, PCA, exp. Viva Villa, MHL. 
apareció desnudo en la ventana de la habitación de su hotel en el centro y orinó sobre cadetes mexicanos que marchaban en la calle), la película se terminó en Hollywood. Algunos periódicos mexicanos pidieron la incautación de la película filmada en México antes de que el equipo de la MGM abandonara el país. Sólo después de que la Secretaría de Gobernación, que había aprobado el proyecto, garantizó públicamente que la película no iba a denigrar a México, la controversia amainó. ${ }^{22}$ En 1934, la PCA dio a la película su sello de aprobación, crucial para su exhibición doméstica, bajo la estipulación de que la exhibición mexicana se había autorizado a través de las consultas de la MGM con el gobierno mexicano. ${ }^{23}$

La versión final de ;Viva Villa! representaba al dirigente revolucionario mexicano como una figura vulgary analfabeta, aunque bien intencionada, capaz de una tremenda brutalidad, una combinación de bandido social y de noble salvaje. La campaña de publicidad de la MGM articulaba esta imagen. $\mathrm{Al}$ formular una historia modelo de la película para distribución a la prensa, el departamento de publicidad de los estudios describió a Villa como "un símbolo de esperanza y

22 Josephus Daniels a sD, 28 noviembre 1933 , NA RG-59, 812.4061 MP/130; "Película que puede resultar denigrante para México", El Universal, 20 noviembre 1933, y "Un actor de la película infamante está preso", El Universal Gráfico, 20 noviembre 1933, incluido en Record Group 84, Embajada de la Ciudad de México [NA RG-84.

23 Joseph Breen a Louis B. Mayer, 4 abril 1934, PCA, exp. Viva Villa, MHL. miedo extrañamente mezclados". Se acentuaba el contexto nacional de la historia de Villa como derivada del subdesarrollo mexicano:

En otras épocas su tipo podría haber florecido en cualquier parte [...]. En los últimos años -es decir, durante el siglo pasado-, México fue su territorio natural. Porque la idea de vivir de Villa no era algo que venía de él sino de su suelo, el suelo de un país oprimido, primitivo $y$ atrasado. En un país en el que un puñado de ricos terratenientes controlan la vivienda y la alimentación de toda la población y abusan o complacen a los trabajadores a su antojo, es inevitable que surja un Robin Hood en defensa de la gente. Un Robin Hood que despiadadamente ataca y saquea a los ricos con el fin de ayudar a los pobres -0 , al menos, lograr que los pobres ya no sean golpeados y desposeídos. 24

A pesar de las controversias que restringieron la filmación en México, la MGM enfatizó la autenticidad de la película en una publicidad que manifestaba: "El número total de mexicanos nativos que tomaron parte en la película, del primero al último, es de más de 100 000." Los estudios hicieron alarde de que a veces "los actores dormían en suelos de baldosas fríos, envueltos en sarapes nativos y comían la comida nativa". La campaña de publicidad de la película implicaba que

24 "Special Sunday Feature: Pancho Villa Returns", Viva Villa, Pressbook, p. 17, Film Collection, New York Public Library for the Performing Arts, Lincoln Center Branch [en adelante citado como NYPLPA]. 
¡Viva Villa! no fuera sólo una historia, sino un intento de relatar la historia reciente. ${ }^{25}$

Al mismo tiempo, la MGM trató de aplacar al gobierno mexicano usando la publicidad de la película para distanciar el México contemporáneo del de la época de Villa y promoviendo el turismo mexicano - un sector clave en la visión estatal de la economía en desarrollo del país- entre los consumidores estadunidenses. Esto no sólo sirvió a los intereses a largo plazo de Hollywood-que dependian de relaciones internacionales amistosas y de un mercado mundial abierto a la cooperación con los gobiernos extranjeros-, sino que también fue importante a corto plazo para el destino de ;Viva Villa! en el mercado externo, potencialmente más valioso. El México posrevolucionario, según la publicidad de la MGM, era seguro y tranquilo, un buen vecino para Estados Unidos y un destino seguro de vacaciones para los turistas estadunidenses. La publicidad de los estudios citaba a la estrella de jViva Villa!, Wallace Beery, diciendo: "Viajar por México hoy es totalmente seguro y bastante cómodo [...]. Los tiempos de los bandidos han pasado y todos los buenos mexicanos esperan que hayan pasado para siempre. El país es pacifico, bien vigilado y el alojamiento en las ciudades es tan bueno como en cualquier ciudad similar de Estados Unidos." Y cuando la autopista entre Laredo, Texas y la ciudad de México "esté terminada, México espera un

25 “ 'Viva Villa!' Filmed in Native Mexican Lo. cale", Viva Villa Pressbook, p. 9, NYPLPA. gran flujo de turistas y se prepara para recibirlos con su típica hospitalidad" ${ }^{26}$

Si bien el México urbano satisfacía los niveles turísticos normativos de Estados Unidos, en el campo los estadunidenses de clase media podían experimentar la premodernidad como un contrapunto del desarrollo de la sociedad estadunidense. Beery indicaba:

La mayor parte de /Viva Villa!, como es lógico, se filmó en el interior del país, lejos de los trillados caminos de los turistas. Esta parte de la república sigue siendo primitiva pero pacífica. La gente es hospitalaria en general y ofrece al viajero norteamericano lo mejor que tiene. Con frecuencia se niega a recibir ningún pago. Tienen una curiosidad ingenua por los "norteamericanos", como nos llaman, que es refrescante y a veces vergonzosa.

Además de sus atracciones coloniales y prehispánicas, México, "un país virtualmente sin máquinas", ofrecía culturas indígenas que Europa no podía ofrecer. Beery prevenía que viajar por el interior en México acarreaba riesgos para los estadunidenses: "En primer lugar, no se podía esperar que el estómago estadunidense asimilara los alimentos nativos sin quejarse [...]. El agua potable es un problema que los turistas deben estar preparados a enfrentar." Pero también esto era presentado por la MGM como un atractivo: la experiencia premoderna al alcance con sólo cruzar el río Bravo. Además, el subdesarrollo proporcionaría a los

26 "Wallace Beery Comments on Mexico", Viva Villa, Pressbook, p. 14, NYPLPA. 
turistas estadunidenses no sólo ventajas espirituales y recreativas, sino también "beneficios económicos", seguía el artículo, pues "los gastos para vivir en el interior del país son ridículamente bajos". El consumidor estadunidense encontrará gangas hechas por artesanos que "con herramientas burdas [...] modelan maravillosas obras de filigrana en plata y oro, trabajando días en un artículo que no les dará más que unos cuantos pesos en el mercado". 27

En una película aparte ofrecida por el departamento de publicidad de la MGM, el actor mexiconorteamericano Leo Carrillo, que tenía un papel secundario en iViva Villa!, proclamaba: "Si es verdad que el mejor humor es humor inconsciente, entonces los mexicanos son la gente más divertida de la tierra[...]. No me propongo faltar al respeto al excelentemente educado pueblo mexicano, ni al natural de Ia raza." Tal vez la MGM también se refería a los mexicanos de habla inglesa, ya que las historias atribuidas a Carrillo implicaban inglés mal hablado por mexicanos dando por supuesto, incluso en el contexto de anécdotas apócrifas, que los mexicanos tienen que ser capaces de comunicarse con fluidez en el idioma de sus vecinos. Uno de esos chistes era:

While we were filming iViva Villa! a mexican standing next to me dropped

27 Ibid. Para un examen del papel del premodernismo y el primitivismo como atracción de los intelectuales estadunidenses, artistas y organizaciones culturales hacia México a fines de los años veinte y treinta, véase Delpar, Enormous y Pike, United States, 1992, pp. 235-243 y pp. 272-281.

EL CINE Y LAS RELACIONES CULTURALES hishat. Remembering mygoodspanish rearing I picked it up and handed it to him.

He said politely, "Thank you very much".

I said, "Don't mention it".

He said, "No, by golly, I won't tole [sic] nobody". ${ }^{28}$

El gobierno mexicano aprobó /Viva Villa! para exhibición. Al público mexicano le atrajo y la película se exhibió varios meses. Pero en general no fue bien recibida por los intelectuales y políticos mexicanos que la consideraron denigrante. Sindicatos nacionales y organizaciones de campesinos boicotearon la película, y hubo un caso en que provocó una revuelta en un cine, lo que contribuyó a su retiro obligado de la circulación mexicana. A pesar de las precauciones tomadas por Hollywood para asegurar la aprobación oficial, jViva Villa! fue un punto bajo en las relaciones de Hollywood con el gobierno mexicano. ${ }^{29}$ En el caso de ;Viva Villa!, el gobierno mexicano, no por última vez, trató infructuosamente de configurar la película estadunidense según el proyecto ideológico del régimen a través de la colaboración con Hollywood. ${ }^{30}$

${ }^{28}$ Carrillo, "My nine", p. 14, NYPLPA.

29 "Mexico City", Variety, 16 enero 1934, p. 52; "MGM Opens 'Viva Villa'", Variety, 18 septiembre 1933, p. 4. Véase también Petit, Images, p. 220; Delpar, Enormous, pp. 174-175; Woll, Latin, pp. 45-49; Garcia Riera, México, pp. 212. 221.

${ }^{30}$ México prohibió otra película estadunidense sobre Villa, The shadow of Pancho Villa, que consideró difamatoria, y obligó a retirarla de las pantallas de varios países latinoamericanos en 1934. Véase Leo R. Sack, embajador de 
¡Viva Villa! demostró el poder de Hollywood en la representación de la historia mexicana. El deseo del Estado mexicano de contrarrestar esas representaciones y hacer uso de la película para propaganda nacional estimuló su intervención durante principios de los años treinta en la industria en desarrollo de películas sonoras, que debido a su novedad y su potencial de crecimiento, implicó la participación económica y administrativa de importantes elites posrevolucionarias como el presidente Abelardo Rodríguez y el ex secretario de Hacienda y Relaciones Exteriores, AlbertoJ. Pani. ${ }^{31}$ Sin embargo, la intervención directa del Estado mexicano - con fines ideológicos-en la producción nacional fílmica llegó a su punto máximo en los años de Cárdenas.

La industria fímica estadunidense admitió el compromiso del Estado cardenista con la producción de películas centradas en temas históricos y culturales. De particular relieve fue

Costa Rica a SD, 20 marzo 1934, NA RG 59, $810.4061 \mathrm{MP} / 20$.

31 En 1932, Abelardo Rodríguez se convirtió en jefe de un grupo que reorganizó y expandió la Nacional Productora de Películas, que había puesto en circulación la primera película sonora importante de México, Santa (1931); Pani encabezó otro grupo -incluyendo a otros miembros de gabinetes anteriores como Aarón Sáenz y al presidente del Banco de México Agustín Legorreta-que fundó la Cinematográfica Latino Americana, S.A. (CLASA) en 1934. CLASA produjo la película de Fernando de Fuentes, jVámonos con Pancho Villa! (1935), analizada más adelante, así como el musical ranchero de Fuentes, Allá en el Rancho Grande (1936) -crucial para el desarrollo nacional e internacional de la industria cinematográfica mexicana-, producido por el propio Pani.
¡Vámonos con Pancho Villa! de Fernando de Fuentes (1935), la primera película de su importante trilogía sobre la revolución mexicana. Como con otras películas históricas, la administración de Cárdenas sancionó oficialmente la película y ayudó a su producción a través de subsidios económicos y apoyo logístico. Hollywood la consideró, correctamente, como un intento mexicano de contrarrestar las representaciones estadunidenses de la revolución mexicana en películas como iViva Villa! (1934) -que las elites políticas mexicanas veian como despreciativas, pero que habían demostrado la popularidad de la historia mexicana para públicos domésticos-, afirmando una interpretación nacionalista del villismo. ${ }^{32}$

En 1935, el Estado mexicano adoptó una línea más dura hacia Hollywood sobre la representación. Por ejemplo, a fines de 1935, la Secretaría de Gobernación mexicana prohibió la película de United Artists In caliente que protagonizaba Dolores del Río. En 1931, la artista estadunidense nacida en México había actuado en la película de RKO Girl of the Rio, segunda versión de una película muda anterior de United Artists (The Dove, 1927) que había sido prohibida en México. Aunque se permitio que Girl of the Rio se exhi-

32 Villa fue un tema predominante en la construcción de mitos para los primeros productores mexicanos de películas sonoras. Además de Fuentes, para otros cineastas prominentes como Arcady Boytler (El tesoro de Pancho Villa, 1935) y Miguel Contreras Torres (Revolución, 1932, que como Fuentes recibieron apoyo del cjército en la reconstrucción de escenas de batalla, véase Ramírez, Miguel, 1994, pp. 38-40. 


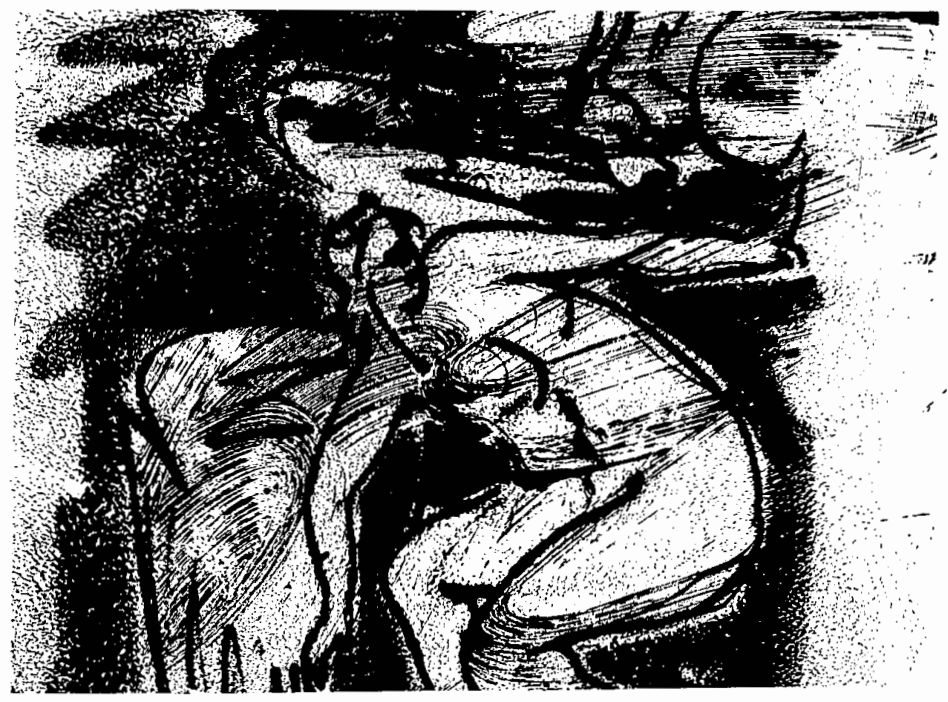

biera en México, fue muy censurada por políticos y críticos mexicanos por su descripción difamatoria del señor Tostado (Leo Carrillo), ${ }^{33}$ un lascivo empresario mexicano suplantado en su interés amoroso por un anglo, más favorablemente descrito, Johnny Powell (Donald Reed), así como por sus declaraciones sobre la corrupción mexicana. Al planear el asesinato de Johnny Powell, el señor Tostado explica a un gringo asociado:

Well, you see in my country [Mexico]

33 Varias de las obras citadas anteriormente (véase nota 2) mencionan Girl of the Rio en relación con una discusión amplia sobre la reacción mexicana a la película, que se exhibió en México como La paloma, véase Garcia Riera, México, pp. 158-162.

EL CINE Y LAS RELACIONES CULTURALES this is the way it is done. Someone give the boss of the jail some dinero and the boss of the jail give the guard some of his dinero, and the guard he fall asleep, leave the door unlocked and $\mathrm{Mr}$. Johnny Powell he makes the slip. Everybody make big holler and the guard who don't got no dinero, he say the prisoner run away. [Imitating the firing of a gun] Plop, plop.

Al aconsejar la censura de In $\mathrm{Ca}$ liente, un diplomático mexicano en Los Ángeles aludió a Girl of the Rio al acusar a Dolores Del Río de malinchismo:

Es muy mexicana cuando está en México; pero no siente ninguna simpatía por su patria, pues está casada con un americano y todas sus costumbres y sus 
tendencias son americanas. Nada tendría esto de particular cuando hay miles de renegados mexicanos; pero lo que sí llama la atención es que después de que en México se le recibe a ella y a su esposo con muestras de alta consideración, venga a denigrar a nuestra patria en esa forma [In caliente] y no es la primera vez. ${ }^{34}$

A pesar de escenas que representaban a los mexicanos estafando a turistas estadunidenses alojados en el hotel Baja California, que servía de pretexto a la película, el cónsul general mexicano recomendó que podía exhibirse en México. Pero a pesar de todo no se permitió su exhibición. ${ }^{35}$ No cabe duda de que la censura mexicana de In caliente estaba dirigida tanto a desalentar a Hollywood de hacer películas que perjudicaran el turismo estadunidense como a proteger las sensibilidades de los mexicanos. De todos modos, su censura representaba una política más nacionalista hacia Hollywood.

El desarrollo del sector filmico doméstico combinado con el control estadunidense de la historia y la cultura mexicanas interactuó con la orientación nacionalista de un Estado que era sensible al poder de los medios de comunicación de masas. Además de motivaciones domésticas, el gobierno mexi-

\footnotetext{
${ }^{34}$ Citado en Silvano Barba González, Secretaria de Gobernación a SRE, 24 junio 1935, III234-6, SREAH.

35 Joaquín Terrazas, cónsul mexicano, Los Ângeles, a SRE 5 agosto 1935; Manuel J. Sierra, subsecretario, SRE a Secretaría de Gobernación, 12 agosto 1935; Esteban García de Alba, Secretaría de Gobernación, 23 agosto 1935; III-234-6 SREAH. Véase también García Riera, México, pp. 204-205.
}

cano trató de promover una industria nacional de películas sonoras como un medio para desafiar la hegemonía cultural de Hollywood que amenazaba el prestigio internacional de México. Una industria filmica nacional llena de vitalidad no sólo iba a configurar la opinión del primer mundo en países como Estados Unidos, del que México dependia económicamente, sino que iba a extender la influencia regional especialmente América Central, vistas por el Estado mexicano como parte de su esfera económica y política de influencia. Al instar a la intervención estatal en la industria del cine sonoro, un diplomático mexicano en Costa Rica observó:

Cuando faltan temas propios, o por razones políticas, aprovechando la revolución de México, California hizo ensayos de temas mexicanos, las más de las veces denigrantes para nuestro país, tuvo desde luego ocasión de observar que el tema mexicano llamaba la atención y era simpático, y que constituía un filón que le convenía explotar, y que explotó. ${ }^{36}$

El diplomático mexicano instaba a que la producción fílmica nacional podría borrar las representaciones negativas de Hollywood, sirviendo como

un maravilloso vehículo del que México se puede valer para destruir la propaganda denigrante de sus enemigos, para atacarlos a su vez, y para llevar al mundo, en fin, en toda su pureza, cl

36 "La película mexicana en Costa Rica", p. 5, Salvador Martínez de Alva, Legación de México, San José, Costa Rica, 16 enero 1937, III-165-23, SREAH. 
mensaje de su propia cultura y de la política social de su gobierno. ${ }^{37}$

Objetivos nacionales e internacionales se combinaban en el plan cinematográfico más ambiciosamente nacionalista de la administración de Cárdenas: el desarrollo de un Instituto Nacional de la Industria Cinematográfica. El instituto iba a combinar la censura oficial con la inversión gubernamental en películas (que considerara progresistas) a través de la extensión regularizada de subsidios y crédito, algo que hacía algún tiempo pedían los productores mexicanos. ${ }^{38}$ El proyecto cultural del Instituto tenía intención de promover la ideología oficial en las producciones domésticas y de excluir las películas extranjeras consideradas antimexicanas. Para que una película extranjera obtuviera la entrada en México, no podía manifestar ninguna de las siguientes características, sumamente subjetivas:

Calidad artística inferior, exaltación de motivos religiosos, idealización del capitalismo, idealización de cualquier religión, ataques a México o a la raza mexicana, expresión de sentimientos imperialistas, ataques al idealismo revolucionario y al proletariado, ofensas a la moralidad, propaganda tendiente a demostrar la superioridad de ciertas nacionalidades.

Los impuestos de exportación a la producción nacional y los derechos

37 Ibid., p. 12.

38 "Es un hecho la ayuda al cine nacional", $E l$ Cine Gráfico, 9 septiembre 1935, p. 3; "State Aid Being Urged for Mexico Industry", Motion Picture Herald, 23 agosto 1935, p. 44. de aduanas se tenían que duplicar, pero las películas distribuidas por el instituto pagarían la mitad. Los aranceles sobre la importación iban a subir en $100 \%$, y la legislación propuesta manifestaba: "Las películas extranjeras que han obtenido permiso para entrar en el país se entenderá que serán exhibidas bajo los auspicios del instituto." 39

La misión del instituto estaba dirigida a ofrecer resistencia a la hegemonía cultural y económica de la industria cinematográfica estadunidense a través de una regulación radical que organizara mejor económicamente el sector filmico doméstico, proporcionara incentivos para la producción de películas que reflejaran la ideología oficial y limitara el libre flujo de películas estadunidenses basadas en criterios nacionalistas determinados estatalmente. En un importante periódico hollywoodense del ramo se publicó que "el instituto estará exclusivamente a cargo de orientar y controlar la industria filmica nacional en todas sus fases". El analista fílmico de la embajada de Estados Unidos pensaba que el principal objetivo y potencial resultado del Instituto iba a ser

la eliminacióngradual de peliculas estadunidenses en México. En lo que respecta a las empresas mexicanas, nuestros productores estarian completamente a merced del Instituto. Perderían su representación mexicana y la distribución de sus películas estaría regulada únicamente por una compañía gubernamental cu-

39 Lockett, Informe especial núm. 14, 16 agosto 1935, Record Group 151, NA RG 151, exp. $128 \mathrm{x}$, pp. $7-8$. 
yo propósito primordial es producir, distribuir y exhibir películas. ${ }^{40}$

Aunque el instituto no estaba planeado como tal, los principales programas que desarrolló fueron asumidos, aunque menos radicalmente, por el Estado. Más tarde, en 1935, se estableció un nuevo departamento en la Secretaría de Gobernación para censurar y editar películas nacionales y extranjeras basadas en estándares nacionalistas oficiales. En cuanto a la producción doméstica, el departamento tenía intención de asegurarse que las películas mexicanas de exportación fueran "lo más puramente mexicanas posible, podándolas de demasiada influencia extranjera, especialmente estadunidense". ${ }^{41}$ También en 1935 , el gobierno mexicano inició un arreglo de cuentas con Hollywood tratando de proteger radicalmente al sector fílmico doméstico a través de tarifas y cuotas de importación más altas a las películas extranjeras y a través de nuevos incentivos económicos a la producción y la distribución doméstica.

II

Los aspectos culturales de la política de Buena Vecindad de Roosevelt ad-

${ }^{40}$ Lockett, Informe Especial núm. 14, 16 agosto 1935, NA RG 151 , exp. $128 x$, pp. $7-8$; "State Aid Being Urged for Mexico Industry", Motion Picture Herald, 23 agosto 1935, p. 44.

11 Lockhart, "Review", 1935, p. 104. En 1942, el gobierno apoyó el desarrollo de una institución de crédito nacional privada para la produc. ción de peliculas que asumió el apoyo financie. ro después de la segunda guerra mundial: el Banco Cinematográfico. quirieron impulso a lo largo de los años treinta cuando el gobierno estadunidense se interesó cada vez más en la influencia del Eje en América Latina y cuando la recuperación económica de Estados Unidos llegó a depender más y más del comercio hemisférico. Como lo han mostrado varios historiadores de las relaciones exteriores de Estados Unidos, en los años veinte y treinta, aun cuando el Departamento de Estado se interesó cada vez más por las iniciativas culturales, se valió de un sistema privado existente generado por organizaciones internacionales filantrópicas, educativas y culturales. Aunque coordinó y alimentó cada vez más esa actividad, no fue sino hasta 1938, con el establecimiento de la División de Relaciones Culturales (cuya zona primordial fue América Latina), cuando el gobierno de Estados Unidos financió y planeó activamente programas. ${ }^{42}$ Además, en la mayor parte del periodo de entreguerras, las actividades institucionales culturales implicaron contactos de alta cultura $e$ individuales: intercambios de estudiantes, visitas al extranjero de artistas, académicos e intelectuales. Existían programas dirigidos a públicos más amplios (también llevados a cabo por organiza. ciones privadas), pero, de modo similar, estaban orientados a elites latinoamericanas, como la construcción de

42 La División de Relaciones Culturales creció a partir de las propuestas de intercambios culturales y de información hechos por Estados Unidos en la Conferencia Interamericana de 1936 en Buenos Aires, donde Estados Unidos también ofreció la no intervención incondicional en los asuntos internos de otros países del hemisferio occidental. 
bibliotecas de lengua inglesa, conciertos musicales selectos o exposiciones de arte. ${ }^{43}$ Aunque muy poco examinada por los historiadores, la División de Relaciones Culturales y las instituciones privadas trabajaron con importantes y desarrollados programas de educación visual y propaganda cinematográfica para y sobre América Latina que prefiguraban proyectos gubernamentales de la segunda guerra mundial y de la guerra fría.

El desarrollo de sociedades latinoamericanas de masas en los años treinta presentó nuevos retos a las políticas

13 Delpar ofrece un examen de actores culturales individuales $\mathrm{e}$ institucionales en las relaciones Estados Unidos-México en The enormous. Para un análisis de la evolución de las relaciones culturales estadunidenses estructuradas privadamente en América Latina y su transformación en programas globales del Departamento de Estado, véase Frank Ninkovich, Diplomacy, 1981; Emily Rosenberg proporciona una sintesis que examina el papel de las comunicaciones internacionales en las relaciones exteriores estadunidenses en Spreading, 1981;J. Manuel Espinosa, Inter-american, 1977, ofrece un análisis de la transición de las políticas culturales gubernamentales a fines de los años treinta. Trabajos más recientes se han centrado más atentamente en el papel de los medios de comunicación en las relaciones exteriores de Estados Unidos con América Latina durante los años treinta: José Luis Ortiz Garza ofrece un ex. celente panorama de las políticas estadunidenses en los medios de comunicación en México, concentrándose en la segunda guerra mundial pero con una importante cobertura de la transición en las actividades estadunidenses, también a fines de los años treinta, en México, 1989; Fred Fejes examina el papel de la radio de onda corta en la política estadunidense con América Latina durante los años treinta y la segunda guerra mundial en Imperialism, 1986; James Schwoch ofrece un enfoque menos centrado en el estado de las relaciones de los medios de comunica. ción en American, 1990. culturales exteriores estadunidenses que alentaron la experimentación con películas. El gobierno de Estados Unidos había usado películas en programas de información doméstica destinados a apoyar proyectos del New Deal. Basándose en estas experiencias a fines de los años treinta, el cine fue de especial interés para funcionarios estadunidenses interesados en la penetración cultural de América Latina, donde las tasas de alfabetización eran bajas, con imágenes de la vida estadunidense dirigidas a fomentar la modernización social, difundiendo la cultura de consumo y diseminando propaganda política. Pero antes de la segunda guerra mundial el propio gobierno de Estados Unidos sólo lo experimentó de modo limitado, trabajando más a través de organizaciones no gubernamentales.

Como uno de los primeros empeños para facilitar las iniciativas privadas, la División de Relaciones Culturales envió una circular a los puestos diplomáticos estadunidenses pidiendo información sobre distribución y exhibición filmica "informativo-educativa" y de "propaganda" en los países latinoamericanos. La información se necesitaba por dos razones: para entender la extensión y la práctica de la circulación no comercial de películas, incluidos asuntos prácticos como tarifas, disponibilidad de equipo de proyección y lugares, y para evaluar los programas filmicos de otros países para poder determinar el desafio internacional, especialmente del Eje, a la propaganda estadunidense. ${ }^{44}$

${ }^{14}$ George Messersmith, SD, a cierto diplomá- 
México tenía interés primordial para el Departamento de Estado y el jefe de la División de Relaciones Culturales visitó la ciudad de México a principios de 1939 para revisar los programas estadunidenses. En México, los funcionarios estadunidenses encontraron el sistema de producción y de distribución cinematográfica no comercial más extenso de América Latina que operaba principalmente a través de los ministerios de Educación Pública y Salud Pública. Diversas instituciones educativas ubicadas en ciudades y poblaciones disponían de proyectores de 36 y de 16 milimetros. La Secretaría de Educación Pública también operaba unidades móviles de proyección para prestar servicio a escuelas rurales y a otras instituciones públicas en la provincia. El Departamento de Estado compartió esta información con las fundaciones privadas que tomaron parte en sus iniciativas culturales en América Latina. ${ }^{45}$

Uno de los principales grupos fue la Fundación Rockefeller, que a fines de los años treinta desempeñó un papel importante en el desarrollo de programas de educación visual para públicos de masas en América Latina, donde

tico estadunidense y funcionarios consulares, 5 diciembre 1938, NA RG 59, 800.4061/32; Ben Cherrington, jefe de la División de Relaciones Culturales a Davis, 14 noviembre 1938, NA RG59, 800. 4061/33; Davis a Cherrington, 18 noviembre 1933, NA RG 59, 800.4061 MP/34. De modo similar se reunió información del Departamento de Estado para radio de onda corta, véase Fejes, Imperialism, 1986, pp. 92-93.

45 Josephus Daniels a SD, 3 marzo 1939 , incluyendo "Report on non-recreational and propaganda films", preparado por el vicecónsul Norman L. Christianson, NA RG 59, 800.4061 MP/ 64. tenía compromisos desde hacía muchos años. ${ }^{46}$ La Fundación Rockefeller se involucró en el cine en México a través de su apoyo al American Film Center (AFC), fundado en 1938, que se concentró en América Latina, y más tarde a su afiliado, el International Film Center (IFC), que asumió proyectos del AFC extendiéndolos a otras regiones del mundo. Estas organizaciones eran completamente dependientes de los fondos de la Fundación Rockefeller. Experimentaban con películas como un medio para la modernización social del tercer mundo - para promover la alfabetización, la salud y la higiene, cultura laboral estadunidense y habilidades empresariales y habilida. des en lengua inglesa - a través de la educación visual. Lo hizo en coordinación y a instancias del gobierno de Estados Unidos, "empeñandose en seguir las indicaciones y satisfacer las solicitudes de películas procedentes del Departamento de Estado", como el IFC explicó en un informe a la Fundación Rockefeller. ${ }^{47}$ El IFC estaba bien

46 La Fundación Rockefeller también financió, en la preguerra, la expansión de programas culturales estadunidenses por radio de onda corta en América Latina en los años treinta, véase Fejes, Imperialism, 1986, p. 102. Para un entendimiento de estas instituciones filantrópicas interesadas en América Latina véase Cueto, Missionaries, 1994.

47 Memoranda del International Film Center [en adelante citado como IFC] a la División de Humanidades de la Fundación Rockefeller, 7 mayo 1940, Rockefeller Foundation Collection (en adelante citado como RFC), RG 1.1, Serie 200, caja 199, exp. 2385, Rockefeller Archive Center, Pocantico Hills, Nueva York (en adelante citado COMO RAC). 
situado para este trabajo ya que su presidente, James T. Shotwell, estaba entre el círculo interno de intelectuales estadunidenses que asesoraban a la División de Relaciones Culturales. Su patrocinador, la Fundación Rockefeller, era una de las organizaciones privadas principales en el desarrollo de proyectos latinoamericanos de la División. ${ }^{48}$

En un periodo en que las expectativas populares estadunidenses sobre el papel del gobierno de Estados Unidos en el mundo no incluían todavía gastos de tiempos de pazy definitivamente ningún programa cultural de masas dirigido al mundo en desarrollo, las organizaciones educativas transnacionales, con intenciones liberales internacionalistas, cumplieron la agenda cultural en desarrollo del gobierno estadunidense y sirvieron como vehículos de transición hacia la diplomacia cultural moderna. Como lo observó el director del IFC, Donald Slesinger, la organización "existe en buena medida, para prestar servicios a la División de Relaciones Culturales del Departamento de Estado en situaciones en que es más adecuado que funcionen organizaciones educativas privadas que el propio gobierno". Los proyectos de la Fundación Rockefeller también buscan "suplir el trabajo del Film Service de Estados Unidos" (distribuidor doméstico de películas gubernamenta-

${ }^{48}$ Para entender el involucramiento de Shotwell y de la Fundación Rockefeller en el desarrollo de la División de Relaciones Culturales, véase el informe de 20 abril 1938 preparado por la División de las Repúblicas Americanas para "Proposed informal meeting to consider a program for the promotion of intellectual and cultural relations", NA RG 59, 810.42711/513. les que se había desarrollado como un brazo informativo del New Deal) facilitando la propagación latinoamericana de sus películas educativas. ${ }^{49}$

Una red de organizaciones estadunidenses privadas interactuó con el IFC, involucrando a individuos conectados con la política exterior y corporaciones internacionales, incluidos los estudios de Hollywood. Dos instituciones, estrechamente involucradas en su trabajo, fueron de particular significación para el sistema fílmico estadunidense que operaba en México: la MPPDA, representada en las reuniones del consejo de AFC por su presidente Will Hays, aseguraba la cooperación de Hollywood; y la recientemente fundada Filmoteca del Museo de Arte Moderno (MOMA) (como el propio Museo, una empresa de Rockefeller) que prestaba servicios como instalación de producción (para doblaje, subtitulado y edición) y como un centro de distribución para las películas del IFC. El director de la MPPDA reconoció la utilidad general de promover películas (incluidas las no lucrativas) a nuevos públicos para la expansión internacional de Hollywood, introduciendo películas estadunidenses a públicos nuevos. La filmoteca del MOMA, dirigida por John Hay "Jock" Whitney, proporcionó servicios cruciales técnicos y burocráticos desde el periodo de transi-

49 Donald Slesinger a Lowell Mellett y Robert Horton, 1 agosto 1940, RFC, RG 1.1, Seric 200R, caja 199, exp. 2385, RAC. Como se analiza más adelante, en 1939 el Film Service de los Estados Unidos empezó a desarrollar su propio sistema de distribución latinoamericana para películas estadunidenses de propaganda y educativas. 


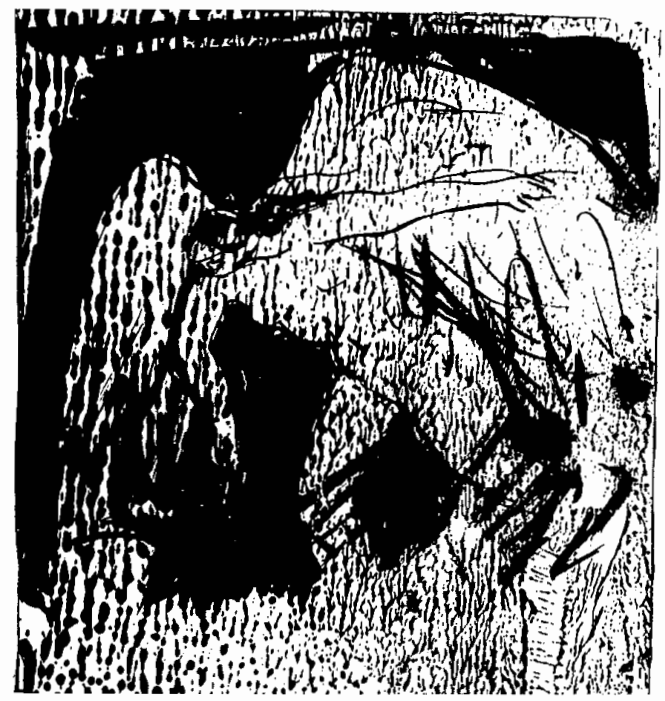

ción hasta el desarrollo de un aparato internacional cinematográfico del gobierno estadunidense. ${ }^{50}$

Uno de los primeros proyectos del IFC, fue un panorama general de las condiciones cinematográficas latinoamericanas que aclara las interconexiones entre intereses filmicos filantrópicos, gubernamentales y comerciales. Como lo explicó el IFC,

${ }^{50}$ Whitney, un productor independiente de Hollywood, proporcionó mucho del financiamiento de la producción de David Selzníck, Lo que el viento se llevó. Más tarde fue el primer director de la Motion Picture Division de la agencia gubernamental, en tiempo de guerra, de Nelson Rockefeller, la Oficina del Coordinador de Asuntos Interamericanos (OCIAA). El MOMA ayudó a la ociaA en la producción y distribución de películas para y sobre América Latina durante la segunda guerra mundial. este panorama era una compilación de información procedente de muchas fuentes que abarcan películas teatrales $y$ no teatrales americanas en la otra América, producción local, legislación $y$ otros datos pertenecientes a la importación y exportación de películas en cada país.

Además de la Fundación Rockefeller y del Departamento de Estado, la "demanda del informe por parte de organizaciones como el American Council of Learned Societies, el Twentieth Century Fund y la Motion Pictures Producers and Distributors of America", fue tan grande que se publicó de manera privada para difundirse a organizaciones internacionales comerciales y educativas. ${ }^{51}$

${ }^{51}$ El IFC a la Fundación Rockefeller, 7 mayo 
El desarrollo de películas realizado por el IFC para su Serie de las Repúblicas Americanas "sobre las regiones, recursos y cultura de América Latina" reflejaba también esas interconexiones. El "comité supervisor" de dicha serie incluía la red usual de figuras educativas y diplomáticas asociadas con el sistema público/privado de relaciones culturales interamericanas desarrollado en la década de 1930, incluidos dirigentes corporativos como T.J. Watson, fundador de la corporación International Business Machines (IBM), que suscribió y supervisó para ella la producción de "una película sobre el comercio mundial". El IFC decidió que esas películas se distribuyeran en Estados Unidos para fomentar las conexiones transnacionales en la promoción de ideas y prácticas capitalistas-liberales, congruentes con la ideología internacionalista de libre comercio de Cordell Hull, el Departamento de Estado y corporaciones e instituciones culturales de mentalidad similar. ${ }^{52}$ La Serie de Repúblicas Americanas demostró el carácter ambiva. lente de las iniciativas filmicas estadunidenses en América Latina. Mientras que otras películas eran enviadas a los países latinoamericanos para promover metas dominantes estadunidenses de índole socioeconómica, cultural y política, la Serie de las Repúblicas Americanas se produjo para públicos estadunidenses y para reconstruir en las mentes de los estadunidenses la idea de los latinoamericanos como una for-

1940, p. 1, RFC, RG 1.1, Serie 200R, caja 199, exp. 2385, RAC.

52 lbid., p. 7. ma que facilitara la explotación y la integración de la región por parte de elites estadunidenses privadas y del sector público. Una mayor intervención económica y política requería de un nivel de consenso público y también de energía doméstica que esas películas estaban destinadas a promover. Esto fue particularmente importante para las relaciones Estados Unidos-México, dado el tratamiento abrumadoramente negativo de las políticas nacionalistas mexicanas a la corriente principal de las noticias en los medios de comunicación (incluidos noticieros) durante la década de 1930.

El IFC estaba particularmente orgulloso de la exitosa extensión internacional de su sistema y de su capacidad "para tratar directamente con gobiernos extranjeros". ${ }^{53}$ Tuvo contactos particularmente buenos con el régimen de Cárdenas. ${ }^{54}$ Después de 1938 (en muchos aspectos un punto más bien alto que bajo en las relaciones mexiconorteamericanas), el Estado mexicano participó en el desarrollo de un sistema internacional de medios de comunicación de masas, dirigido cada vez más por el Departamento de Esta-

53 IFC a la Rockefeller Foundation, 7 mayo 1940, p. 8, RFC, RG1.1, Serie 200R, caja 199, exp. 2385, RAC.

54 Por ejemplo, para 1940 la Fundación Rockefeller intercambió películas con la Secretaria de Sahubridad Pública mexicana a través de canales establecidos por la Secretaría de Relaciones Exteriores; véase embajador Francisco Castillo Nájera, Washington, D.C., a SRE, 26 junio 1940 y Dr. Ricardo D. Alduvin, Oficina Técnica de Educación Higiénica, Departamento de Salubridad Pública, 28 junio 1940, III-2400. 6, SREAH. 
do pero operado por instituciones educativas privadas e intereses de los me dios de comunicación. A medida que creció la importancia de México para Washington, que sus políticas domésticas se hicieron más moderadas y que sus intereses políticos internacionales coincidieron con los de Estados Unidos, se desarrollaron vínculos interestatales y transnacionales más profundos entre ambos países. ${ }^{55}$

Mientras que el IFC y otras prominentes organizaciones de educación visual, como la Harmon Foundation, ${ }^{56}$ expandieron sus sistemas de distribución en México hacia fines de los años treinta, el Estado mexicano colaboró no sólo en la distribución sino también en la producción de propaganda liberal hacia México. ${ }^{57}$ En 1939, la

55 Demuestro este modelo en las relaciones económicas entre Hollywood y el Estado mexicano durante la década de los años treinta en la versión completa de la ponencia de la que se deriva este artículo. Alan Knight ofrece un punto de vista similar en "The rise and fall of cardenismo, c. 1930-c. 1946", en Leslie Bethell (comp.), Mexico, 1991, pp. 284-288.

56 Informe especial núm. 153, 18 noviembre 1938, Thomas H. Lockett, Agregado comercial ciudad de México, NA RG 151, exp. 128x.

${ }^{57} \mathrm{~L}$ as agencias gubernamentales de medios de comunicación a fines de los años treinta empezaron a buscar vínculos cinematográficos con México para distribuir películas de propaganda del New Deal, como la de Pare Lorenz, The plow that broke the plain, y a su vez difundir en Estados Unidos propaganda filmica mexicana que estaba al servicio de los intereses mutuos del ré gimen de Cárdenas y del gobierno estadunidense durante la última fase de la política de Buena Vecindad; véase Luis Quintanilla, encargado de $\mathrm{Ne}$ gocios, Embajada Mexicana, Washington, D.C., a Pare Lorents (sic), director de Documentales, el National Emergency Council, Nueva York, 11 de octubre 1938, III-370-1, parte IX, SREAH.
División de Repúblicas Americanas del Departamento de Estado envió al subsecretario Sumner Welles una propuesta sobre "la perspectiva de un subsidio Rockefeller para la producción de una película sobre el 'el New Deal de México'". El informe explicaba que el director del IFC Donald Slesinger había "declarado confidencialmente que el presidente Cárdenas tenía en mente la producción de una película representando el 'New Deal' de México. Se realizará bajo los auspicios del Ministerio de Educación", producida por un cineasta que había hecho películas de propaganda del New Deal para el Departamento de Agricultura de Estados Unidos. Slesinger sometió la idea a la aprobación del Departamento de Estado, poniendo en claro "que parte del costo de su producción se recaudará de fuentes privadas en Estados Unidos".$^{58}$ Después del estallido de la segunda guerra mundial, a medida que se profundizaban las relaciones entre los dos países, el gobierno mexicano trató de explotar la propaganda estadunidense para sus propios objetivos internacionales y domésticos. ${ }^{59}$

III

A partir de 1939, desarrollos internacionales en Asia y Europa permitieron

${ }^{58}$ Briggs a Welles, 31 agosto 1939 y Carring. ton a Briggs, 28 agosto 1939, NA RG-59, 812.4061 MP $/ 175$.

59 Examino este tema en "Film, nationalities, and State ideologies in mexican-US relations during the $1940 \mathrm{~s}$ ", ponencia inédita presentada en la Latin American Studies Association, International Congress, Atlanta, Georgia, 12 marzo 1994. 
y obligaron a la política exterior estadunidense a desarrollar progresivamente políticas públicas latinoamericanas más innovadoras en la búsqueda de intereses estratégicos, económicos y políticos interrelacionados. El Departamento de Estado consideró al cine como un arma ideológica clave. El gobierno asumió más y más de las responsabilidades que se habían dejado a instituciones culturales no gubernamentales y el sistema informal elaborado entre el Estado y Hollywood desde principos de los años treinta se profundizó volviéndose cada vez más formal. En señal de esta tendencia, hacia fines de 1939, el Film Service de Estados Unidos (antes estrictamente un organismo doméstico) solicitó informes de todos los productores cinematográficos importantes de ese país respecto a "qué producciones se planean, están en marcha o están listas para la circulación que sean primordial o únicamente para el mercado latinoamericano". En una industria que dependía doméstica e internacionalmente de su relación con el Estado, el interés expreso del gobierno en este tipo de producción fue tan significativo como un acuerdo más instrumental. Las respuestas indicaban los esfuerzos emprendidos por varios de los estudios para producir películas y noticieros de entretenimiento (con narración en español) acentuando América Latina o ideas e imágenes que el gobierno estadunidense deseaba difundir en la región. ${ }^{60} \mathrm{El}$ informe anual de la MPPDA de

${ }^{60}$ George Gercke, jefe de Distribución e Información de U.S. Film Service, a Pare Lo-
1939 subraya ese intento de colaboración. Will Hays declaró: "Que la industria responde a nuestra política nacional de buena voluntad y vecindad, se manifiesta en las películas realizadas o planeadas sobre temas de interés para todos los países del continente americano." 61

Warner Brothers, que puso en circulación en 1939 Juárez, iba a representar un paso crucial en la evolución de relaciones de colaboración entre el gobierno de Estados Unidos y Hollywood en proyectos exteriores culturales/ideológicos. Tanto el Departamento de Estado como el IFC (que era un asesor de la Warner Brothers) participaron en el desarrollo de la película y en la difusión latinoamericana. ${ }^{62}$

Aunque la Warner Brothers era el estudio más liberal e importante de Hollywood y tenía fuertes vínculos con la administración Roosevelt, el desarrollo de Juárez representó tendencias más amplias en la relación de de la industria con la política exterior estadunidense. ${ }^{63}$ Más que otra cosa, la

rentz, director US Film Service, 7 enero 1939; "Production plans of major motion picture companies for the latin american market", en Gercke a Ellis $O$. Briggs, jefe a cargo de la Division of the American Republics, SD, 7 enero 1939, NA RG 59, $810.4061 \mathrm{MP} / 54$.

61 Will $\mathrm{H}$. Hays, The enlarging scope of the screen: Annual report to the motion picture producers and distributors of America, Inc, 27 march 1939, Nueva York, MPPDA, folleto, 1939 , p. 19.

62 Slesinger a Mellett y Horton, 1 agosto 1940, p. 2, RFC, RG 1.1, Serie 200R, caja 199, exp. 2385, RAC.

${ }_{63}$ Muchos de los otros estudios estaban dirigidos por republicanos, pero todos compartian una perspectiva internacionalista liberal sobre 
coincidencia de intereses ideológicos y económicos así como las estrechas relaciones organizativas facilitadas por la MPPDA entre Hollywood y el gobierno produjeron esfuerzos como Juárez, que fue el primero (y más monumental) de muchos de esos proyectos latinoamericanos emprendidos por cada uno de los estudios durante la segunda guerra mundial, no sólo para beneficio de los públicos latinoamericanos sino también para convencer a los ciudadanos estadunidenses de que debían apoyar las políticas de Buena Vecindad. ${ }^{64}$

Juárez acentuó los vínculos democráticos entre el desarrollo político mexicano y el estadunidense, representando al héroe mexicano como a un Lincoln latinoamericano. A principios de la película, poco después de recibir una carta de apoyo del presidente de Estados Unidos, Juárez contempla el retrato de Lincoln que ésta incluye (y sigue exhibiéndose insistentemente en toda la película), y con esta inspiración procede espontáneamente a escribir un mensaje al pueblo mexicano proclamando que la lucha contra el imperialismo francés encar-

los asuntos exteriores relacionados con sus intereses económicos, pero también con creencias ideológicas más amplias inherentes a la cultura moderna estadunidense de corporación. Para las orientaciones políticas de los diversos directores de estudios, véase Neal Gabler, Empire, 1988.

${ }_{64}$ Para un primer relato general de "Hollywood's good neighbor policy", incluidos comentarios sobre Juárez, véase Woll, Latin american, pp. 53-75; para el involucramiento del Departamento de Estado en Juárez, véase Paul J. Vanderwood, "Image", 1992, pp. 221. 244. na la causa de la "verdad, la libertad y la justicia", causas políticas que eran paralelas a la ideología estadunidense y que no amenazaban con desorden social. La publicidad de la Warner Brothers hacía esas conexiones explícitamente personales. Por ejemplo, un artículo principal, indicado por el departamento de publicidad de los estudios, titulado "Lincoln was his hero" empezaba así:

Tres años después de que una pobre india en una choza de adobe cerca de Ixtlán en el estado de Oaxaca, México, daba a luz al niño que el padre bautizó Benito Pablo, en una cabaña de madera, en los bosques de Kentucky, otra pobre mujer blanca, de nombre Nancy Hanks, trajo al mundo al niño al que Tom Lincoln puso por nombre Abraham. ${ }^{65}$

Warner Brothers construyó a Juárez como a un hombre medio, autodidacta y santo laico, arraigado en la mitología popular de Lincoln. Además, la lucha de Juárez estaba a favor y se basaba en el capitalismo democrático que formaba los mitos nucleares del desarrollo estadunidense.

Los franceses y sus aliados conservadores mexicanos simbolizaban una amenaza de la penetración del viejo mundo y su explotación de las fuerzas antiliberales del viejo orden en el nuevo mundo. La película representaba a los grupos latinos antiestadunidenses como amenaza reaccionaria a la soberanía nacional más que como posibles bastiones contra el imperialismo estadunidense. Este mensaje-que ad-

65 Harry Lee, "Lincoln was his Hero", Juárez, Pressbook, NYPIPA. 
vertía contra los peligros de la penetración fascista y que vinculaba históricamente a América Latina con la ideología liberal de unos Estados Unidos progresistas, opuesta a modelos autoritarios europeos fuera de modaexpresaba claramente la retórica del Departamento de Estado. Como el duque de Morny (Frank Reicher) recordaba a Napoleón III: "La recaudación de la deuda de México era de importancia secundaria [ante la provocación de la intervención francesa]. Su majestad intervino en México para bloquear la difusión de la democracia estadunidense."

$\mathrm{Al}$ referirse a su relación con México, Napoleón III (Claude Rains) se describía orgullosamente a sí mismo como un "autócrata supremo" que desdeñaba la "democracia" como "el gobierno del rebaño por el rebaño, para el rebaño. Abraham Lincoln, parlamentos, plebiscitos, proletarios, una muchedumbre intoxicada con ideas de igualdad, jrebaño! ¿Me va a destruir esa porquería?" Además, al trazar los paralelos del racismo nazi que alineaba a la étnica y racialmente pluralista sociedad estadunidense con el mestizaje mexicano, el emperador francés pondera si el "imperialismo francés" será derrotado "en manos de Benito Juárez, un bandido indio, o hemos de esperar a que los yanquis nos destruyan en el río Bravo". En su benevolente construcción de la Doctrina Monroe, Juárez acentuaba los vínculos naturales entre la política exterior estadunidense y la soberanía latinoamericana. Cuando la emperatriz Eugenia (Gail Sondeergaard) recomienda la imposición de un monarca amigo de los inte- reses franceses y de sus conservadores aliados mexicanos, Napoleón III pone en duda si eso provocaría la intervención estadunidense. Ella le recuerda, en palabras que equivalían a una declaración de principios de una política oficial de Buena Vecindad, que: "La doctrina Monroe se aplica únicamente a la toma de territorio estadunidense por potencias europeas, no a los asuntos internos de los países americanos." ${ }^{66}$ Como lo dijo un guionista, "todo niño debe ser capaz de darse cuenta de que Napoleón, en su aventura mexicana, no es otro que Mussolini y Hitler en su aventura española". ${ }^{67}$

Juárez fue un intento consciente no sólo de propaganda política, sino también de revertir el resentimiento latinoamericano (en especial el mexicano) causado por las representaciones derogatorias de la historia latinoamericana, como en iViva Villa! La Warner Brothers acentuó sus esfuerzos para lograr autenticidad mediante la consulta con expertos; anunciaron que los estudios habían obtenido 350 libros, "en español", sobre historia mexicana, incluidos "cincuenta volúmenes procedentes de la biblioteca del ex presidente Adolfo de la Huerta". La publicidad de los estudios in-

66 Uno de los rasgos principales de la política de Buena Vecindad fue la gradual renuncia oficial al Corolario Roosevelt (Theodore, 1904) de la doctrina Monroe, que se había aplicado para incluir la intervención en los asuntos domésticos de países del hemisferio occidental en nombre de la seguridad internacional y el interés nacional de Estados Unidos.

${ }^{67}$ Citado en Vasey, "Hollywood's global distribution", p. 632. 


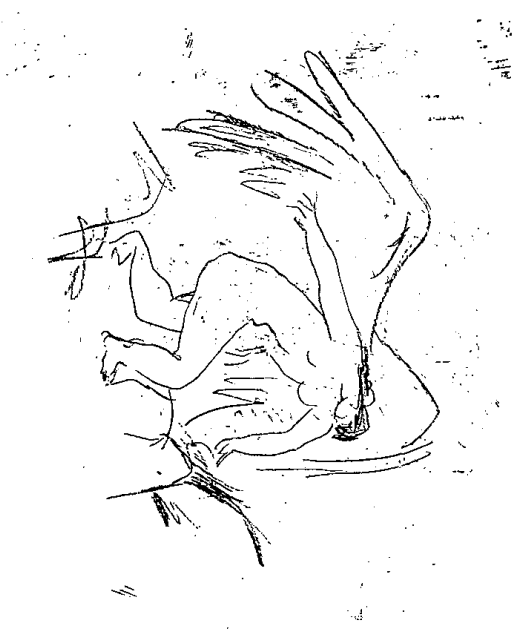

sistía en que "esos libros estaban en uso constante en los estudios durante la producción para asegurar la precisión histórica de la película". ${ }^{68}$ Además, los actores de Juárez-advertía la publicidad de los estudios a través de retratos comparativos--, se parecían extrañamente a las figuras históricas que retrataban. ${ }^{69} \mathrm{La}$ versión de Hollywood sobre la historia no iba a ser meramente diversión sino una forma de escolaridad popular. La Warner Brothers afirmaba que su investigación y trabajo de campo en México iba

68 "Wide research made for 'Juarez'", Juarez, Pressbook, p. 13, NYPLPA.

69 'How the 'Juarez' stars resemble their historical twins", Juarez, Pressbook, p. 18, NYPLPA. a llenar un vacío en la autocomprensión mexicana, como se citaba a Paul Muni en la publicidad de los estudios: "México no ha tenido grandes historiadores. ${ }^{n 70}$

Esta nueva sensibilidad respecto de América Latina, reflejaba la influencia del Departamento de Estado así como los intereses económicos de Hollywood, que dependían cada vez más de los ingresos latinoamericanos a medida que las condiciones políticas en Europa y Asia cerraban sus mercados a los productos estadunidenses a fines de los años treinta. Además, reforzaba las políticas contra el Eje del propio Estado mexicano. En 1939, el activismo de la CTM, condujo a una prohibición nacional de todas las películas italianas y alemanas. ${ }^{71}$ Lombardo Toledano hizo una pública defensa de la película Juárez. ${ }^{72}$ La campaña de publicidad de Warner Brothers subrayaba el papel de ésta en las relaciones internacionales. La publicidad de Juárez incluía fotografias de figuras políticas clave estadunidenses y mexicanas asistiendo a su estreno en Nueva York, así como citas de importantes diplomáticos y dirigentes políticos mexicanos y estadunidenses que suscribían la película, incluidos el presidente Cárdenas, el embajador Daniels y el dirigente laboral estadunidense John L. Lewis. ${ }^{73}$

70 'Film executives go to Mexico for 'Juarez' Data", Juarez, Pressbook, p. 12, NYPLPA.

71 Daniels a SD, 11 abril 1939, NA RG 59, 812.4061 MP/170.

${ }^{2}$ Embajador Quintanilla a SRE, 20 abril 1939, III-404-10 SREAH.

73 "What the notables say about 'Juárez'", Juárez, Pressbook, pp. 6·7, NYPLPA. 
Juárez se estrenó en México en el Palacio de Bellas Artes ante un público que incluía al embajador de Estados Unidos, Daniels. ${ }^{74}$ El régimen de Cárdenas parecía complacido por la producción. En una visita a Ciudad Juárez, el presidente Cárdenas asistió a una exhibición especial de la película, facilitada por el consulado de Estados Unidos, más de un mes antes de que se estrenara oficialmente en la ciudad de México. Cárdenas proclamó que era una excelente representación del héroe legendario mexicano. ${ }^{75} \mathrm{El} \mathrm{embaja-}$ dor Quintanilla asistió al estreno de la película en Washington e informó que, a pesar de errores históricos, retrataba positivamente a México como un país dedicado a la democracia e iba a ofrecer una imagen internacional favorable. ${ }^{76}$

El Departamento de Estado movilizó a su servicio exterior para informar sobre la acogida latinoamericana de Juárez. ${ }^{77}$ La reacción mexicana varió y los dirigentes políticos conservadores, los de la oposición y los periódicos, consideraron que la película describía a México y a Juárez como dependientes de Estados Unidos para derrotar a los franceses y derrocar a Maximiliano. ${ }^{78}$ En $\mathrm{El}$ Universal, Eduar.

${ }^{74}$ Daniels a SD, 27 junio 1939, "Impressions created by the picture 'Juarez'”, 811.4061 Juárez/8.

75 William P. Blocker, cónsul general de Estados Unidos, Ciudad Juárez, 1 julio 1939, 811.4061 Juárez/11.

${ }^{76}$ Quintanilla, 27 abril 1939, III-404-10, SREAH.

77 Instrucción del Departamento de Estado, 8 junio 1939, 811.4061 Juárez/6a. La respuesta a esta solicitud fue voluminosa. Para fines de este artículo citaré sólo unas cuantas muestras.

${ }^{78}$ Véase Josephus Daniels a SD, 27 junio

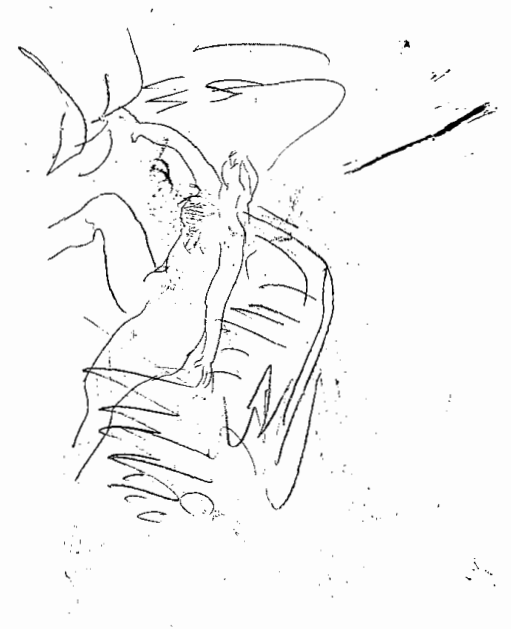

do Pallares, un ex callista, escribió condenando a Juárez como una versión de las formas en que Hollywood degradaba el "alma nacional" de México:

Cada día que pasa somos menos mexicanos y estamos más inclinados a imitar a nuestros vecinos[...]. Nuestras incultivadas doncellas aspiran a ser rubias platino o neuróticas Greta Garbo, y se las ve por todas partes imitando costumbres y modales que no armonizan con nuestra constitución material y moral.

Con la película Juarez se ha iniciado algo más grave en el campo de esa invasión cultural. La propaganda da por sentado un carácter político y por me-

1939, "Impressions created by the picture 'Juárez'", NA RG-59, 811.4061 Juárez/9. 
dio de esto nuestras masas analfabetas reciben una versión tendenciosa y falsa de nuestra propia historia, y se les indican los beneficios de la Doctrina Monroe sin que ellos se den cuenta en qué medida nos degradan el tutelaje humillante y la intervención ominosa en nues. tros propios destinos de los políticos y los gobiernos estadunidenses. ${ }^{79}$

La opinión popular fue menos extremosa, con diversas críticas de aspectos particulares de la película pero sin expresiones dramáticas de hostilidad o gratitud. En general, hubo un gran interés público en la película, ayudado por estrenos especialmente organizados en todo el país. Pero éste no fue siempre el caso. En Durango, el vicecónsul de Estados Unidos no advirtió que la película promoviera ningún sentimiento particularmente "amistoso en los mexicanos locales hacia Estados Unidos", y que las perspectivas de "cualquier resultado benéfico" procedente de la película como propaganda proestadunidense "eran prácticamente nulas". ${ }^{80}$ En Guaymas, la película fue bien recibida. Pero miembros del público objetaron que "la caracterización de Díaz [John Garfield], en especial la escena de la cárcel que lo muestra comiendo maíz de la mazorca, fuera verdad o no, era un tanto ofensiva para las susceptibilidades mexicanas". ${ }^{81}$

${ }^{79}$ Eduardo Pallares, "Juárez", El Universal, 4 julio 1939, incluido en Daniels a SD, NA RG 59, 6 julio 1939, 811.4061 Juárez/17.

${ }^{80}$ E.W. Eaton, vicecónsul estadunidense, Durango a SD, 4 noviembre $1939,811.4061$ Juárez/50.

81 James C. Powell, Jr., vicecónsul estadunidense, Guaymas, 9 noviembre 1939, NA RG 59, 811.4061 Juárez/51.
Muchos mexicanos entrevistados por funcionarios estadunidenses consideraron que una película sobre Juárez debería estar en español. Respecto a toda América Latina la pregunta general que interesaba al Departamento de Estado era si la película era consiclerada o no como franca propaganda, lo cual (según informes diplomáticos) en general no lo era.

La atención cada vez mayor de Hollywood sobre América Latina acarreó nuevos mitos ideológicos y tecnológicos construidos según lineamientos estadunidenses. En muchos aspectos, Juárez significó una competencia renovada para los productores mexicanos sobre el tema de la historia mexicana, capital en las películas mexicanas más populares realizadas en los años treinta. México era, desde hacía mucho tiempo, el "otro" nacional en la narrativa de Hollywood sobre el desarrollo estadunidense, y se reconstruía ahora en Juárez como una versión latinoamericana de Estados Unidos.

La nueva versión en 1939 del cineasta mexicano Miguel Contreras Torres de su película anterior Juárez y Maximiliano (1933), ahora titulada The mad empress, ofrece un ejemplo de cómo la nueva atención prestada a México por Hollywood interactuó sobre los intentos mexicanos de construir historia popular a través del cine. ${ }^{82}$ Contreras, respondiendo a cambios en las relaciones México-Estados Unidos, quiso aprovechar las relaciones

82 El autor vio Mad empress en la bóveda de los UCLA Film and Television Archives, ubicada en Hollywood. 
de Buena Vecindad para producir The mad empress en Estados Unidos. Su esposa, Medea Novara, actuaba en la película como lo hizo en la versión mexicana. Contreras la rodeó de algunos talentos muy conocidos, incluidos Lionel Atwill [Bazaine], Conrad Nagel [Maximiliano] y un joven Jason Robards [Juárez]. Ante la producción de la Warner de Juárez, Contreras demandó a los estudios estadunidenses por plagio, argumentando que le habían robado su obra anterior. Warner Brothers solucionó el pleito accediendo a distribuir The mad empress a través de Vitagraph, su subsidiaria. ${ }^{83}$

La publicidad estadunidense de The mad empress acentuaba su mexicanidad señalando que "Torres filmó la historia de las vidas del infeliz reinado de la pareja como monarcas mexicanos en algunos de los mismos edificios y habitaciones en que la pareja vivió" ${ }^{84}$ Pero la película fracasó miserablemente en Estados Unidos, y no fue el menor de los motivos su baja calidad técnica y artística. (Por ejemplo, Contreras, exasperantemente, filmó a Robards de espaldas a la cámara a lo

${ }^{83}$ Materiales legales relacionados con $\mathbf{M a d}$ empress están en la caja 2874, Warners Brothers Archive, Special Collections, Film and Television Library, Universidad de California del Sur, Los Ángeles; véase también Miguel Contreras Torres a Lázaro Cárdenas, 1939, SREAH, III-404-10. Gabriel Ramírez aduce que tanto la intervención del Estado mexicano como el temor de la Warner de enfrentar un mercado mexicano restringido para su versión de la historia de Juárez contribuyeron enormemente al compromiso final, véase Miguel, 1994, pp. 53-56.

84 "Actual locals used in film", Mad empress, Pressbook, p. 3, NYPLPA.

EL CINE Y LAS RELACIONES CULTURALES largo de toda la película.) La película de Contreras fue severamente enjuiciada por los críticos y no hizo ninguna mella en la conciencia popular estadunidense. Los críticos mexicanos elogiaron la película -especialmente como un signo de que los productores mexicanos podían competir con Hollywood y ser aceptados por él y por el público estadunidense-, pero la película distó mucho de tener el éxito del Juárez de Warner en el mercado mexicano. ${ }^{85} \mathrm{Y}$ a pesar de la producción mexicana anterior con mayor éxito, Juárez y Maximiliano, el Juárez de Warner-que demostraba el poder cultural de Hollywood-- llegó a eclipsar a ambas películas como representación -en los medios de comunicación populares- de la historia mexicana en todo el hemisferio occidental.

IV

Por último, hemos de tener en cuenta la representación en los noticieros de México y de las relaciones Estados Unidos-México la forma más importante de comunicación audiovisual en una época previa a la televisión. El Estado mexicano trató de hacer uso de este medio para promover el desarrollo económico del país, especialmente del turismo estadunidense, a través de producciones favorables.

Desde el inicio de la producción sonora, Fox's Movietone News, una pro-

${ }^{85}$ Véase Mad empress, Production, exp., MHL; véase también Ramírez, Miguel, 1994, p. 55 y pp. 168-171. 
ductora estadunidense importante, cultivó buenas relaciones con el gobierno mexicano para ganar más acceso y un trato favorable en la producción de sus películas. El gobierno mexicano estaba dispuesto a otorgar concesiones como un anticipo de la propaganda internacional que le iba a ser útil para su proyecto. ${ }^{86}$

En 1931, Fox's Movietone News negoció con la Secretaría de Relaciones Exteriores mexicana (a través de la embajada de Estados Unidos) la producción de una película que ilustrara la amistad Estados Unidos-México y anunciara la construcción de una nueva carretera - parte del sistema de la autopista panamericana- que vinculaba Laredo, Texas, y la ciudad de México. ${ }^{87} \mathrm{El}$ acontecimiento más importante de la película iba a ser la conversación entre el embajador norteamericano J. Reuben Clark y el pre-

${ }^{86}$ La Secretaría de Relaciones Exteriores de México aconsejó a los funcionarios fiscales que respondieran a la solicitud de Fox-Movietone sobre un trato fiscal preferencial en el transporte de un camión y de otro equipo a México en 1928 para producción cinematográfica, ya que "se propone tomar vistas cinematográficas de propaganda a favor de México, se sirva acordar las facilidades que solicita el interesado". El jefe de Protocolo, SRE a Daniel Pozos, director general de Aduanas, Secretaría de Hacienda y Crédito Público, 24 febrero 1928; véase también cable de Bernon T. Woodle, Nueva Orleans, Louisiana a Ge raro Fstrada, subsecretario de Relaciones Exteriores, 22 febrero 1928, y Daniel Pozos, memorándum, 3 marzo 1928; 27-4-122, SREAH.

${ }^{87}$ En realidad, el gobierno de Estados Unidos también planeó una película para promover el desarrollo de la autopista panamericana; véase Circular del Departamento de Estado, 14 agosto 1930, NA RG 84, Embajada de Estados Unidos en México. sidente Ortiz Rubio, discutiendo la importancia de la carretera para las relaciones Estados Unidos-México. El gobierno mexicano y el Departamento de Estado entendieron la importancia de los medios de comunicación de masas en la construcción de ideas populares cruciales para las relaciones políticas y económicas MéxicoEstados Unidos. 88

March of Time -la serie popular pseudodocumental y mensual de actualidades, que combinaba filmación de noticias con acontecimientos reconstruidos- era uno de los críticos más influyentes de México en los años treinta. Producido por la organización Time/Life de Henry Luce, March of Ti$m e$, a medida que se acercaba la gue-

${ }^{88}$ Arthur Bliss Lane a Herschel V. Johnson, jefe a cargo de la Division of Mexican Affairs, SD, 5 diciembre 1930; Lane a don Alfonso Rosenzweig Díaz, jefe de Protocolo, Secretaría de Relaciones Exteriores, 8 diciembre 1930; Lane a Charles W, Herbert, camarógrafo de Fox-Movietone News, 8 diciembre 1930; Lane a Herbert, 7 enero 1931; Herbert a Lane, 10 enero 1931; Herbert a Lane, 12 febrero 1931; Lane a Herbert, 16 febrero 1931; Herbert a Lane, 25 febrero 1931; Lane a Herbert, 28 febrero 1931; Memorándum sin fecha: informando al personal de la embajada de la exhibición privada por Herbert en el cine Regis el 11 de mayo de 1931 de la película que filmó en México; NA RG-84, Embajada en México. J. Reuben Clark había sido un arquitecto clave de políticas exteriores republicanas y uno de los que prefiguraron la primera política de Buena Vecindad de Roosevelt. Como subsecretario de Estado, justo antes de convertirse en embajador en México, Clark había concebido el "Memorandum Clark" rechazando el Corolario Roosevelt a la Doctrina Monroe -que desde 1904 justificaba el uso liberal de la intervención militar estadunidense en América Lati. na-por contraindicado para mantener el dominio estadunidense en la región. 
rra, cooperó cada vez más con el Departamento de Estado en la producción y distribución de sus producciones mensuales de dos rollos, las cuales se centraban en uno o dos temas y duraban alrededor de 20 minutos. ${ }^{89}$ Como Nelson Rockefeller (a quien analizaremos más adelante), Luce era un republicano internacionalista pero menos liberal, más ferozmente anticomunista, más unilateral en su visión de las relaciones internacionales estadunidenses (sobre todo en el tercer mundo, donde él abogaba por la franca búsqueda de la hegemonía de Estados Unidos) y en general más escéptico de Roosevelt que de los negocios de Rockefeller. La representación de México en los noticieros March of Time durante los años treinta reflejaba esos valores.

March of Time empezó a producirse en 1935 y desde su inicio México fue tema prominente. A mediados de los treinta, antes de que las condiciones generales de los asuntos mundiales reconfiguraran las relaciones México-Estados Unidos, March of Time se refería al Estado mexicano como comunistoide, acentuando su anticlericalismo y un nacionalismo económico radical y extraviado, temas que manifestaban la principal corriente de opinión conservadora estadunidense. En

${ }^{89}$ Para un panorama de esta serie, incluida una filmografia, véase Raymond Fielding, March, 1978. March of Time también tenia un programa de radio que se distribuía en México durante la segunda guerra mundial en estaciones que colaboraban con la Oficina del Coordinador de Asuntos Interamericanos y cadenas radiofónicas estadunidenses. Véase Ortiz Garza, México, 1989 , pp. 137-140.
Mexico! (1935), el narrador nos dice: "El jefe político del gobierno de México, Plutarco Elías Calles, imita a la Rusia soviética sin Dios, tratando de desarraigar toda religión de México." El noticiero describe después un levantamiento local contra un maestro rural ateo al que un tropel de campesinos cuelgan, poniéndole en torno al cuello un letrero que dice: "Por enseñar educación socialista."

Por consejo del cónsul mexicano en Los Ángeles, el gobierno mexicano prohibió la exhibición de Mexico!, e inició una protesta prolongada ante el gobierno estadunidense. El embajador mexicano Francisco Castillo Nájera informó sobre el tratamiento derogatorio a su gobierno y se opuso a su exhibición - tanto en Estados Unidos como en el ámbito internacional-ante el secretario de Estado, Hull. El Departamento de Estado simpatizó con la posición del gobierno mexicano, haciendo infructuosas peticiones informales a March of Time para que alterara la película. Castillo Nájera se quejó de que la filmación de March of Time, que utilizaba dramatizaciones con actores, presentaba con falsedad la ficción propagandística como realidad. La falsedad dramática de imágenes de la película, con campesinos asesinando al maestro, llevaron a Castillo Nájera a declarar: "Me parece tan torpe el desenlace que, repito, gracias a él, la película resulta casi favorable a nuestra propaganda." Aunque en un análisis final Castillo Nájera consideró esa descripción de las políticas del Estado mexicano como totalitarias, y a la sociedad popular en violenta oposición con el gobierno, no cabía duda de 


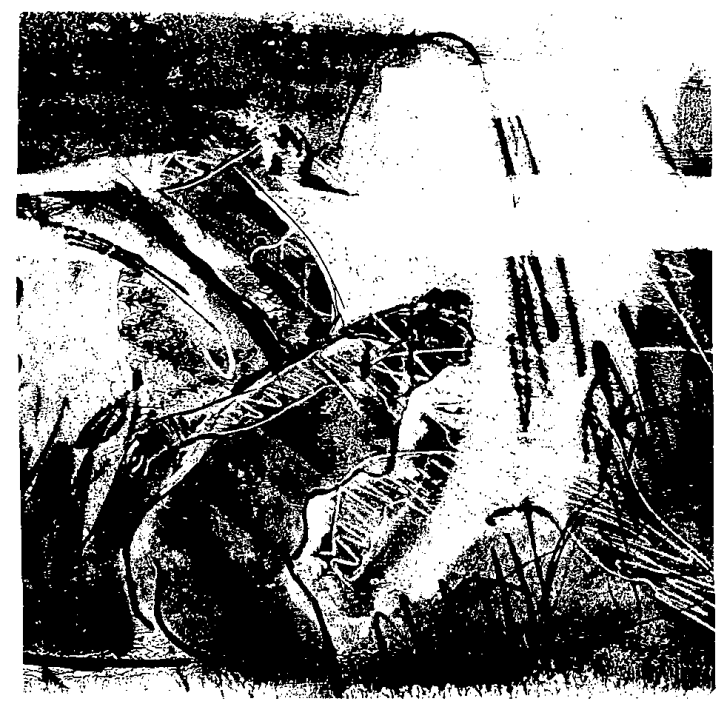

que iban a perjudicar la imagen de México en las mentes de los estadunidenses. ${ }^{90}$ Enojado por su incapacidad para impedir la exhibición de Mexico!, el gobierno mexicano exploró "la posibilidad de ejercer actos de represalia sobre los editores de la película o sobre los distribuidores de la misma, en el caso de que éstos actúen en alguna forma en nuestro territorio". 91

${ }^{90}$ Cónsul mexicano en Los Ángeles a SRE, 28 abril 1935; Francisco Castillo Nájera, Washington, D.C., a SRE, 13 mayo 1935, MI-136.7, SREAH.

${ }^{91}$ Fernando Torreblanca, SRE, a Francisco Castillo Nájera, Washington, D.C., 13 junio 1935 , III-136-7, SREAH. Para contrarrestar la influencia de la representación antimexicana en los medios de comunicación estadunidenses, el partido estatal, Partido Nacional Revolucionario (PNR), también trató de usar la exhibición de
Con el transcurso del tiempo, como en otros casos de producción filmica, la política exterior estadunidense llegó a ejercer influencia sobre la representación de México y de las relaciones México-Estados Unidos mediante March of Time. Reflejando la influencia del contexto cambiante de las relaciones Estados Unidos-México en Mexico's News Crisis (1939), March

propaganda cinematográfica de no diversión en Estados Unidos para influir en la opinión estadunidense sobre México y en especial como un modo de mantener vínculos ideológicos con las comunidades mexicana y mexiconorteamericana en Estados Unidos; véase José María Dávila, secretario general del PNR, a Emilio Portes Gil, secretario de Relaciones Exteriores, 27 mayo 1935; Manuel J. Sierra, jefe del Departamento de Asuntos Políticos, SRE, a la embajada mexicana, 
of Time era más ambivalente pero, en definitiva, crítica del Estado cardenis. ta y sobre todo de la reciente expropiación petrolera. El narrador dice que "la ciudad de México es la sede de un experimento revolucionario, una nueva forma de socialismo estatal que raya en el comunismo". Aunque Cárdenas tal vez tenga buenas intenciones, "su programa radical para socializar la agricultura y controlar la industria encuentra hoy dificultades cada vez mayores". Después de criticar las políticas laborales de Cárdenas, las reformas agrarias y la expropiación petrolera, el narrador asegura al público que, a pesar de todo, "Estados Unidos ha sido un vecino bueno y generoso". A pesar de las buenas intenciones de Cárdenas, el nacionalismo económico mexicano, según March of Time, había amenazado no sólo las relaciones Estados Unidos-México, sino también el bienestar del mexicano promedio al que Cárdenas trataba de servir. El deterioro de la economía nacional, señala-

Washington, D.C., 3 junio 1935; Sierra a Dávila, 3 junio 1935. Considerando la solicitud del gobierno mexicano, que aducía "la calificación de ser de carácter cultural y educativo" para que las películas pudieran entrar en Estados Unidos sin pagar aduanas, el Departamento de Estado quería saber si, entre otras cosas, "las películas muestran la educación rural entre nuestras clases campesinas [...], si son exposiciones pedagógicas sobre la educación socialista, etc.", Francisco Castillo Nájera, embajador, Washington, D.C., a SRE, 25 junio 1935; Sierra a Dávila, 8 julio 1935, III-309-32, SREAH. En los años veinte, el Estado mexicano usó también propaganda cinematográfica en sus relaciones culturales con Estados Unidos, además de participar en la producción de películas del gobierno estadunidense y del sector privado que promovian el desarrollo económico mexicano.

EL CINE Y LAS RELACIONES CULTURALES ba la película, había obligado a México a comerciar desfavorablemente con la Italia y la Alemania fascistas. Sectores industriales clave, como la minería y el petróleo, así como las masas campesinas, habían sido devastados por el nacionalismo cardenista. A medida que escenas de campesinos cruzaban la pantalla, el narrador observaba que lo peor de todo era que "el pueblo que Cárdenas más quiere ayudar $[\ldots]$ encuentra que bajo la mezcla cardenista de comunismo y socialismo el dinero y la comida son cada vez menos abundantes que antes". Pero, en el análisis final, la presentación es ambivalente. El narrador dice que Cárdenas quiere dar al pueblo mexicano "un trato nuevo y mejor", trazando un paralelo con el programa de Roosevelt. Y, en definitiva, también se nos dice que a pesar del descontento justificado de las "clases acaudaladas" mexicanas y del capital extranjero, Lázaro Cárdenas sigue siendo el hombre de su pueblo decidido a hacer de México el primer país completamente socializado en el mundo occidental.

Después de 1939, a medida que el gobierno de Estados Unidos se fue in. volucrando cada vez más en la utilización de los medios de comunicación de masas dominantes en la política exterior interamericana, la organización de Luce (como Hollywood) cooperó con el Departamento de Estado -en buena medida porque, a pesar de las diferencias, su visión reflejaba más o menos la política exterior de la administración: involucrada en los asuntos mundiales, extendiendo la diplomacia pública al tercer mundo, promoviendo mercados abiertos al comercio con 
Estados Unidos-, todo lo cual era importante para las exportaciones de medios de comunicación de masas. El impacto de la política exterior estadunidense pronto se hizo claro a medida que March of Time revisó radicalmente su representación de México. Un año después de poner en circulación el muy crítico Mexico's New Crisis, March of Time dedicó dos rollos enteros (dos veces más tiempo que en el pasado) a otra película sobre México, usando parte de la misma filmación pero con diferentes mensajes, como lo había hecho el año anterior.

En Mexico's Dilemma (1940), March of Time ofrecía una revisión tímida de su anterior descripción del Estado mexicano que se ajustaba a la alianza emergente entre los gobiernos mexicano y estadunidense. March of Time siguió reprendiendo al régimen de Cárdenas pero poniéndolo en la perspectiva del pasado, acentuando en cambio el importante papel de México en la defensa hemisférica y las oportunidades de un desarrollo más metódico y menos radical a través de la cooperación con Estados Unidos.

El noticiero abre con escenas de disturbios civiles, incluidas imágenes de pancartas con lemas antiestadunidenses. El narrador reconoce que muchos estadunidenses "contemplan con grave preocupación los acontecimientos que han trascendido del otro lado del río Bravo en los últimos seis años". Mexico's Dilemma prosigue presentando a Cárdenas como responsable de fomentar ingenuamente una situación revolucionaria. Sobre imágenes de propaganda soviética que se venden en la ciudad de México, el narrador proclama: "Para los jóvenes proletarios de México el programa de [Lombardo] Toledano trajo el evangelio de Marx y Lenin y forjó en el país un constante odio al imperialismo extranjero." La película no niega la existencia de la dominación económica estadunidense, pero está centrada en la confrontación radical de Cárdenas con los intereses estadunidenses, proclamándolos perjudiciales para la búsqueda de la modernidad por parte de Méxicoy abriendo oportunidades para demagogos más peligrosamente radicales y menos bien intencionados que Lombardo Toledano.

La película también pone en duda la legitimidad de las tácticas utilizadas por "la mayor máquina política en el país" para elegir a Ávila Camacho. Pero a pesar de esta crítica de la sucesión de 1940, el noticiero retrata desfavorablemente la candidatura del principal candidato de la oposición, Juan Andrew Almazán. Sobre imágenes del Boletín Acción Nacional, el narrador dice que Almazán estuvo apoyado por "terratenientes e industriales mexicanos que vieron en la dificil situación de aquellos que habían sido decepcionados por la revolución una oportunidad poco frecuente". Además, al espectador se le informa que las fuerzas de Almazán nunca tuvieron el apoyo de Estados Unidos, que fue imparcial en los asuntos mexicanos internos. March of Time describe a la oposición como una reacción peligrosa de derecha provocada "por el estrecho dominio del régimen de Cárdenas".

La segunda mitad del noticiero acentúa el mejoramiento y la renovación 
del espíritu en las relaciones bilaterales en el último año de la administración de Cárdenas. El narrador explica:

Hubo una indicación repentina de cambio en la política de México hacia Estados Unidos y los diplomáticos mexicanos se volvieron prominentes entre los latinoamericanos por buscar la amistad y la buena voluntad del secretario Cordell Hull [...]Mientras que durante muchos meses el asunto principal habían sido las disputas entre Estados Unidos y México, el embajador Francisco Castillo Nájera mostró un nuevo afán de explicar a todos los interesados el deseo de México de cooperar plenamente con su vecino del norte.

Después de imágenes del jefe del estado mayor del ejército estadunidense, George Marshall, conferenciando con oficiales militares mexicanos, la escena pasa a la ciudad de México, donde se muestra al embajador Josephus Daniels conferenciando con funcionarios mexicanos. El narrador comenta que recientemente Daniels "pudo informar a Washington de una mejor atmósfera que la que había vivido en sus tratos anteriores con el régimen de Cárdenas".

Los mensajes dominantes de Mexico's Dilemma eran que para 1940 había quedado atrás una época de radicalismo estatal y que Estados Unidos y México estaban en el umbral de una nueva relación basada en políticas mexicanas más conservadoras y de mayores vínculos produciendo un progreso económico y político en México y una mejor seguridad interamericana respecto al fascismo.

Herbert Bursley de la División de
Asuntos Americanos del Departamento de Estado aprobó Mexico's Dilemma para su exhibición en México. Recomendó algunos cambios para acentuar aún más el compromiso histórico de Estados Unidos con la no intervención en los asuntos mexicanos. Específicamente pidió la eliminación de cualquier indicación del involucramiento de Estados Unidos en la capacitación militar mexicana. También advirtió que

hay unas cuantas escenas que no serán particularmente agradables a los mexicanos, como el tipo bastante bajo de peones que se muestran en algunas escenas; revueltas en tiempo de elecciones; la interferencia con un votante; la implicación de que el gobierno controlaba la elección, etcétera.

Pero sobre todo él creía que "el punto de vista mexicano está tan bien presentado que, con muy poca edición, se podría mostrar en México como propaganda para el gobierno mexicano". El análisis de Bursley incorporaba puntos de vista de representantes de la embajada mexicana, incluido el em. bajador Quintanilla, que habían asistido a una exhibición especial del noticiero por el Departamento de Estado. ${ }^{92}$

92 Bursley a Philip S. Bonsal y Lawrence Duggan, 26 octubre 1940, NA RG 59, 812.4061 MP/ 196. Reflejando las relaciones políticas y económicas México-Estados Unidos, la representación de México de March of Time evolucionó poste. riormente a la guerra. En Tomorrow's Mexico (1946), NA MPSRB RG 20012.10 , Cárdenas es visto heroicamente como un Franklin D. Roosevelt mexicano durante la Depresión, como un liberal, no como un radical, preparando el terreno para un desarrollo más estable después de los 
V

Los programas cinematográficos de la Fundación Rockefeller, el desarrollo y el uso de Juárez como diplomacia de los medios de comunicación, y la evolución de la representación de México y de las relaciones México-Estados Unidos por March of Time, todo prefiguraba los programas fílmicos más amplios de tiempo de guerra emprendidos por el gobierno estadunidense en América Latina. En 1939, la División de Relaciones Culturales del Departamento de Estado empezó a desarrollar un Servicio Cinematográfico Interamericano, planeado como una rama colateral del Film Service estadunidense (véase más arriba), para modificar y distribuir películas del gobierno de Estados Unidos a públicos latinoamericanos, en realidad asumien-

años treinta. Representaba a Ávila Camacho como a un FDR en tiempo de guerra, conduciendo valerosamente a su país a la guerra mundial. Como país, México es promovido como el lugar ideal de descanso para las clases medias estadunidenses de la posguerra en busca de unas vacaciones baratas pero "exóticas", accesibles en automóvil. Time prometía estabilidad y progreso al sur de la frontera. Lo que había cambiado, por supuesto, no era la realidad de Cárdenas sino la realidad de las relaciones México-Estados Unidos. El desarrollo de la representación de México en March of Time reflejaba los cambios en esas relaciones desde finales de los años treinta y la actitud de las instituciones estadunidenses dominantes, incluidos los medios de comunicación. March of Time involucró a la embajada mexicana en la preparación final de la película y trató de mostrársela a Ávila Camacho como un ejemplo de la propaganda internacional favorable al proyecto del Estado mexicano. Véase Antonio Espinosa de los Monteros, Washington, D.C., a SRE, 14 noviembre 1946, y SRE a Espinosa de los Monteros, 28 marzo 1946, III1432-26, SREAH. do muchas de las funciones manejadas por los programas de la Fundación Rockefeller. ${ }^{93}$ Esta propuesta relativamente restringida fue suplantada en 1940 por el establecimiento de la Oficina del Coordinador de Asuntos Interamericanos (OCIAA), bajo la dirección de Nelson Rockefeller, de 32 años, que tenía un antiguo interés en América Latina, donde estaba estrechamente involucrado en los extensos negocios de su familia, y tenía una fascinación particular por México. La ociaA iba a supervisar las relaciones económicas y culturales con América Latina como una agencia independiente del Departamento de Estado, demostrando el reconocimiento gubernamental sobre que América Latina tenía una importancia no sólo estratégica durante la guerra, sino también sobre la necesidad de desarrollar una nueva estructura a largo plazo para preservar la influencia y la dominación de Estados Unidos de manera lo suficientemente flexible para soportar el impacto de la guerra en las relaciones hemisféricas políticas y sociales. La Motion Picture Division de la OCIAA reunió y modernizó muchos de los temas analizados más arriba, implicando el uso en la preguerra de películas sonoras comerciales y no dramáticas en las relaciones de Estados Unidos con América Latina.

Basándose en las innovaciones públicas/privadas de los años treinta, los proyectos filmicos mexicanos de la

93 Véase 26 abril y 16 agosto 1939 , "Minutes of the Interdepartmental Committee on Cooperation with American Republics", NA RG 353 (Records of Interdepartmental and Intradepartmental Committees on the American Republics), registro 20 , caja 20. 
OCIAA combinaban metas económicas y culturales. Representaban la modernización de la diplomacia cultural estadunidense y las prácticas de los medios de comunicación en América Latina que habían sido globalizadas desde la segunda guerra mundial. En cuanto a la producción filmica que implicaba al Estado mexicano, la Motion Picture Division de la OCIAA, que empleaba a profesionales de Holly. wood y de otras industrias cinematográficas, produjo muchas películas (de acuerdo con los lineamientos de la película del IFC propuesta sobre el New Deal de México) representando a México como un país progresista, moderno y democrático dirigido por un Estado liberal. Directa e indirectamente, la OCIAA exhibió esas películas en México, Estados Unidos y otros países latinoamericanos. La Motion Picture Division, trabajando con el Departamento de Turismo mexicano, facilitaba también la colaboración en producción y distribución de documentales de viaje mexicanos, narrados por actores de Hollywood, dirigidos a desarrollar el turismo estadunidense. También produjo, distribuyó y exhibió películas de educación visual destinadas a promover la modernización social al estilo moderno estadunidense en América Latina.

La Motion Picture Division, trabajando a través de su comité de enlace con base en Hollywood, la Motion Picture Society for the Americans (MPSA), influyó en la producción de los estudios de películas de recreación y temas breves concebidos como propaganda interamericana para públicos estadunidenses y latinoamericanos.
Con la asistencia de la MPSA, la OCIAA también modernizó la industria filmica - a través de asistencia técnica directa a los estudios mexicanos- con la intención de producir propaganda proestadunidense más auténtica para públicos latinoamericanos y contrarrestando la influencia de la indsutria cinematográfica argentina. Aunque estaba dictado por los objetivos de po lítica exterior en tiempo de guerra, el papel integral de Hollywood en la planeación y ejecución de los programas cinematográficos del gobierno de Estados Unidos significó que su control de la industria filmica mexicana se profundizara, aun cuando la industria mexicana crecía. En los años treinta, Hollywood estaba directa e indirectamente involucrado en programas cinematográficos internacionales político-culturales promovidos por el gobierno de Estados Unidos durante y después de la segunda guerra mundial.

A medida que la representación de México por medio de Hollywood llegó a ser más positiva, que la ideología oficial y las políticas del Estado mexicano se volvieron menos confrontantes hacia Estados Unidos, y que las estructuras transnacionales entre los dos países se desarrollaron a fines de los años treinta, se disipó la oposición del Estado mexicano a la actitud dominante de Hollywood de producir la historia popular mexicana. Las ideas para el desarrollo de organismos gubernamentales que controlaran la distribución de películas extranjeras - como el Instituto Nacional de la Industria Cinematográfica-y la diplomacia regional dirigida a contrarrestar la hegemonía 
de Hollywood, dieron paso al elogio oficial de las políticas culturales en medios de comunicación de masas de Buena Vecindad, ejemplificadas por Juárez.

A medida que creció el papel del cine en la propaganda estadunidense en los años treinta, la relación de Hollywood con el gobierno de Estados Unidos se intensificó y su penetración en México se volvió más profunda. Nuevos vínculos organizativos de tiempo de guerra entre Hollywood y la industria filmica mexicana, reforzados por lazos ideológicos entre el Estado mexicano y el gobierno de Estados Unidos se desarrollaron aún más durante la guerra fría. En términos de producción cultural, estas nuevas relaciones prepararon el camino para el establecimiento en México, en la posguerra, de un complejo filmico entre el gobierno de Estados Unidos y Hollywood, público y disimulado, más extenso, que implicara la integración y la cooptación de la producción mexicana. Estos nuevos proyectos de colaboración reflejaban la institucionalización de la alianza interestatal política, económica e ideológica desde fines de los años treinta, reforzada por la presencia transnacional de Hollywood en México, que se benefició comercialmente de la relación bilateral en desarrollo.

\section{BiBLIOGRAFÍA}

\section{Princtpales fuentes primarias consultadas en México}

-Secretaria de Relaciones Exteriores, México, D.F.: Archivo Histórico, Archivo Concentración.
-Filmoteca Nacional de la Universidad Nacional Autónoma de México (UNAM), México, D.F.

\section{Principales fuentes primarias} consultadas en Estados Unidos

-National Archives, Washington, D.C., Central Files of the Department of State (Record Group 59). Embassy and Consular Records (Record Group 84).

-Library of Congress, Washington, D.C., Motion Picture and Broadcasting Division, film collection, archives, and library.

- Margaret Herrick Library, Academy of Motion Picture Arts and Sciences, Beverly Hills California, Special Collections, Production Code Administration Collection, Production Files Collection.

-New York Public Library for the Performing Arts, Lincoln Center, New York City, Press Books Collection, Film files.

-Rockefeller Archive Center, Pocantico Hills, New York, Rockefeller Foundation files, Nelson Rockefeller Papers.

-University of Southern California, Doheny Library, Cinema-TV Library, Special Collections, Warner Brothers.

\section{Fuentes secundarias}

-Ayala Blanco, Jorge, La aventura del cine mexicano en la época de oro y después, Grijalbo, México, 1993.

-Britton, John A., Revolution and ideology: Images of the mexican revolution in the United States, University of Kentucky Press, Lexington, 1995. (comp.), Molding the hearts and minds: Education communications, and social change in Latin America, Scholarly Resources, Wilmington, 1994.

-Bethell, Leslie (comp.), Mexico stnce independence, Cambridge University Press, 1991.

-Bureau of Foreign and Domestic Commerce, Motion pictures in Mexico, Cen- 


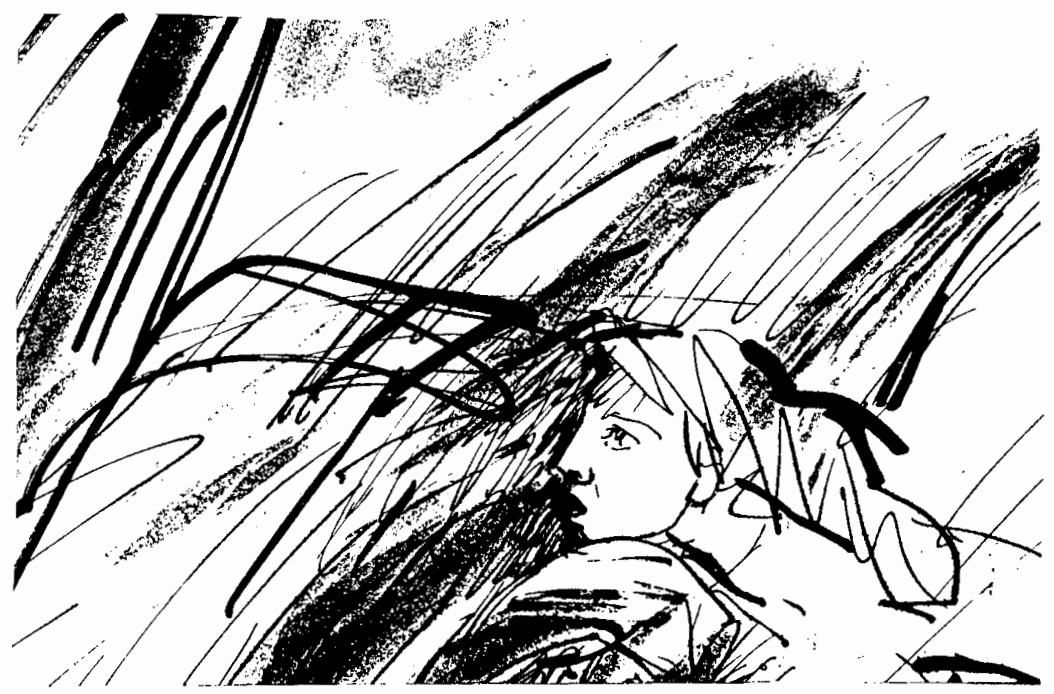

tral America, and the Greater Antilles, Washington, 1931.

-Burton, Julianne, “Don (Juanito) Duck and the imperial-patriarchal unconscious: Disney Studios, the Good Neighbour policy, and the packaging of Latin America", en Andrew Parker et al., Nationalism and sexualities, Nueva York, 1992.

-Carrillo, Leo, "My nine best mexican stories", Viva Villa!, Pressbook, NYPLPA.

-Coatsworth, John y Carlos Rico (comps.), Images of Mexico in the United States, Center for U.S.-Mexican Studies, La Joya, 1989.

-Cobbs, Elizabeth A., The rich neighbor policy: Rockefeller and Kaiser in Brazil, Yale University Press, New Haven, 1992.

Cortés, Carlos E., "To view a neighbour: The Hollywood textbook on Mexico", en John H. Coastworth y Carlos Rico (comps.), Images of Mexico in the United States, San Diego, 1989.
.Cueto, Marcos (comp.), Missionaires of science, The Rockefeller Foundation in Latin America, Bloomington, 1994.

-De los Reyes, Aurelio, Con Villa en México. Testimonios de camarógrafos norteamericanos en la Revolución, 1911 . 1916, Instituto de Investigaciones Estéticas-Universidad Nacional Autónoma de México, México, 1985.

Medio siglo de cine mexicano, 1896-1947, Trillas, México, 1987.

-Delpar, Helen, "Goodbye to the 'Greaser'",Journal of Popular Television and Film, núm. 12, primavera 1984.

, The enormous vogue of things mexican: Cultural relations between the United States and Mexico, 19201935, University of Alabama Press, Tuscaloosa, 1992.

-Dickson, Robert G., "El teatro California, una tradición cultural de los Ángeles vencida por el espíritu de la modernidad", 
La Opinión, Los Ángeles, California, 1 marzo 1992.

"El teatro California ý el legado de Francisco Fouce", La Opinión, Los Ángeles, California, 8 marzo 1992.

-Espinosa, J. Manuel, Inter-american beginings of United States cultural diplomacy, Washington, 1977.

-Fein, Seth, "La diplomacia del celuloide: Hollywood y la Edad de Oro del cine mexicano", Historia y Grafía, núm. 4, primavera 1995.

"Hollywood, U.S.-Mexican relations, and the revolution of the 'Golden Age' of mexican cinema”, Film Historia, núm. 2, junio 1994.

-Fejes, Fred, Imperialism, media, and the Good Neighbor: New Deal foreign policy and United States shortwave broadcasting to Latin America, Ablex Press, Norwood, 1986.

-Fielding, Raymond, The March of Time, 1935-1951, Nueva York, 1978.

-Freeman Smith, Robert, The United States and economic nationalism in $\mathrm{Me}$ xico, 1916-1931, Chicago, 1972.

-Friedman, Lester D. (comp.), Unspeakable images: Ethnicity and the american cinema, Urbana, II, 1991.

-Gabler, Neal, An empire of their own: How the jews invented Hollywood, Nueva York, 1988.

-García Riera, Emilio, Historia documental del cine mexicano, 2a. ed., vols. 110, Universidad de Guadalajara, Guadalajara, 1992-1994.

México visto por el cine extranjero, 6 vols., Ediciones Era/Universidad de Guadalajara, México, 1987-1990.

-González, Luis, Los artífices del cardenismo: historia de la revolución mexicana, 1952-1960, El Colegio de México, México, 1979.

-Hamilton, Nora, The limits of State autonomy: Post-revolutionary Mexico, Princeton University Press, Princeton, 1982.
-Hays, Will H., The enlarging scope of the screen: Annual report to the motion picture producers and distributors of America, Inc., 27 marzo 1939, Nueva York, MPPDA, folleto, 1939.

-Jarvie, Ian, Hollywood's overseas campaign: The North Atlantic Movie Trade, 1920.1950, Cambridge University Press, Nueva York, 1992.

-Joseph, Gilbert y Dan Nugent, Everydayforms of State formation: Revolution and the negotiation of rule in modern Mexico, Duke University Press, Durham, 1994.

Johnson, Randal, The film industry in Brazil: Culture and the State, University of Pittsburgh Press, Pittsburgh, 1987.

-Kaplan, Amy y Donald E. Pease, Culture of United States imperialism, Duke University Press, Durham, 1993.

-King, John, Magical reels: A history of latin american cinema, Verso, Nueva York, 1990.

-Knight, Alan, U.S.-Mexican relations, 1910-1940: An interpretation, Center for U.S.-Mexican Studies, La Jolla, University of California, San Diego, 1987.

"The rise and fall of carde. nismo, c. 1930-c. 1946", en Leslie Bethell (comp.), Mexico since independence, Cambridge University Press, 1991.

-Langley, Lester, America and the Americas: The United States in the western hemisphere, University of Georgia Press, Athens, 1990.

-Lee, Harry, "Lincoln was his hero", Juárez, Pressbook, NPLPA.

-Lockhart, James, "Review Department Set Up", Motion Picture Herald, 19 octubre 1935 .

-López Ana, M., "Are all latins from Manhattan?, Hollywood, ethnography, and cultural colonialism", en Lester Friedman (comp.), Unspeakable images: Ethnicity and the american cinema, Urbana, II, 1991.

-Mora, CarlJ.,Mexican film:Reflecttons 
of a society, 1896-1988, Berkeley, 1982, 1988.

-Niblo, Stephen, War, diplomacy and development:The United States and Mexico, 1939-1954, Scholarly Resources, Wilmington, 1995.

-Ninkovich, Frank, The diplomacy of ideas: U.S. foreign policy and cultural relations, 1938-1950, Cambridge University Press, Cambridge, 1981.

-Orellana, Margarita de, La mirada circular. El cine norteamericano de la Revolución Mexicana, 1911-1917, Joaquín Mortiz, México, 1991.

-Ortiz Garza, José Luis, México en guerra: la historia secreta de los negocios entre empresarios mexicanos de la comunicación, los nazis y E.U.A., Planeta, México, 1989.

-Parker, Andrew et al., Nationalism and sexualities, Nueva York, 1992.

-Petit, Arthur G., Images of the mexican american in fiction and film, Texas A\&M University Press, College Station, 1980.

-Pike, Frederick, The United States and Latin America: Myths and stereotypes of civilization and nature, University of Texas Press, Austin, 1992.

-Pratt, Mary Louise, Imperial eyes: Travel writing and transculturation, Routledge, Nueva York, 1992.

-Ramírez, Gabriel, Norman Foster y los otros directores norteamericanos en México, Universidad Nacional Autónoma de México, México, 1992. Miguel Contreras Torres, 1899-1981, Guadalajara, 1994.

-Roseberry, William, Anthropologies and histories: Essays in culture, history, andpoliticaleconomy, Rutgers University Press, New Brunswick, 1989.

-Rosenberg, Emily, Spreading the ame- rican dream: American economic and cultural expansion, 1890-1940, Hill and Wang, Nueva York, 1982.

-Schiller, Herbert, Mass communication and american empire, Beacon, Boston, 1969.

-Schnitman, Jorge, Latin American film industries: Dependency and development, Ablex Press, Norwood, 1984.

-Schoonover, Thomas, The United States in Central America, 1860-1911, Duke University Press, Durham, 1991.

-Schwoch, James, The american radio industry and its latin american activities, 1900-1939, University of Illinois Press, Urbana, 1990.

-Tomlinson, John, Cultural imperialism: A critical introduction, Johns Hopkins University Press, Baltimore, 1991.

-Thompson, Kristin, Exporting entertainment: America in the world film market, 1907-1934, British Film Institute, Londres, 1985.

-Vanderwood, Paul J., "The image of mexican heroes in american films", Film Historia, núm. 3, octubre 1992.

-Variety, "México City", 16 enero 1934. 18 septiembre 1933.

-Vasey, Ruth, "Foreign parts: Hollywood's global distribution and the representation of ethnicity", American Quarterly, núm. 4, 1992.

-Wagnleitner, Reinhold, The Cocacolonization of the cold war: The Untted States cultural mission in Austria after the second World War, University of North Carolina Press, Chapel Hill, 1994.

-Wood, Bryce, The making of the Good Neighbor policy, Nueva York, 1961.

-Woll, Allen L., The latin image in american film, College Station, Texas, 1980. 


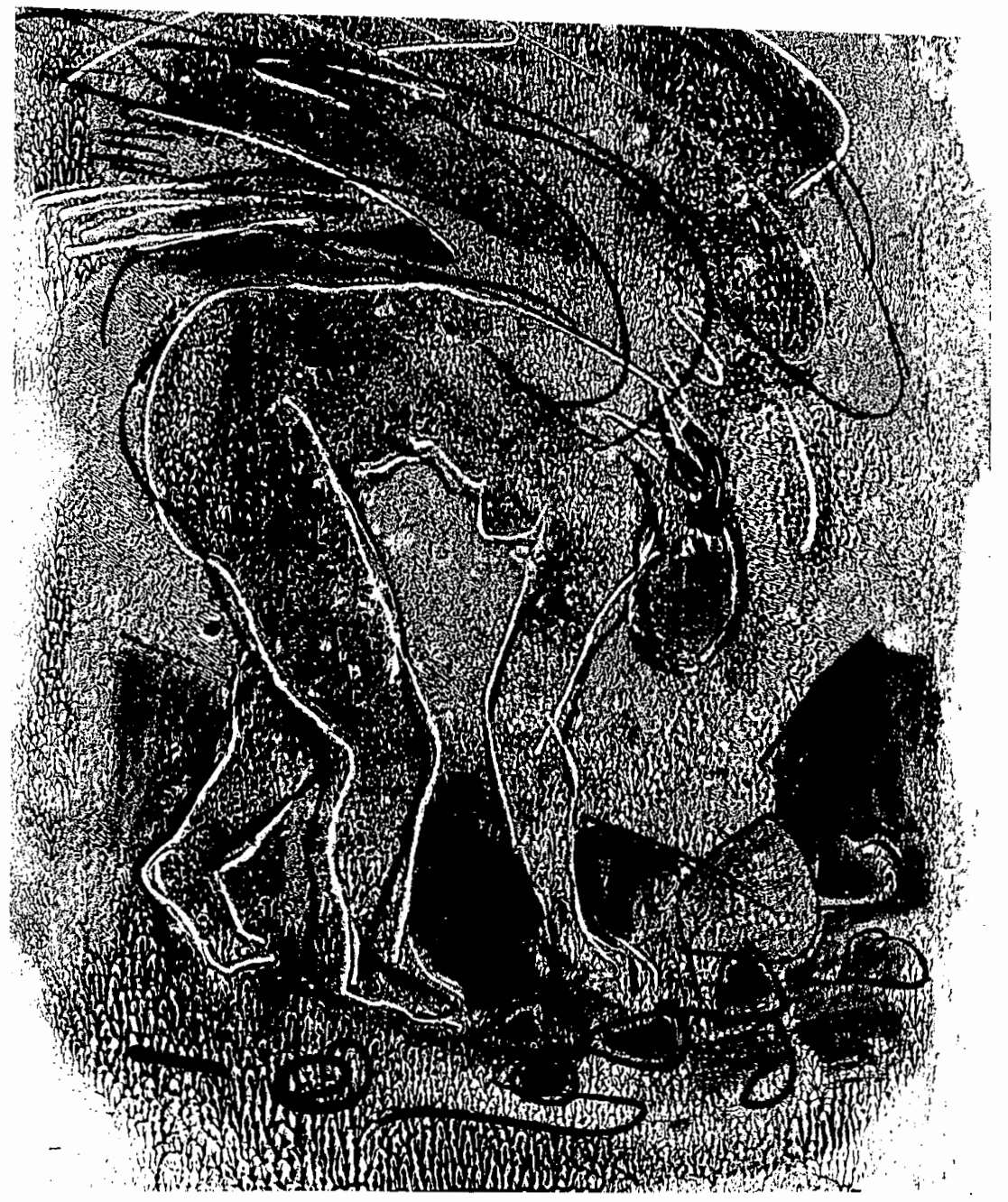

